\title{
Pohled do oken středověkých a raně novověkých domů v českém Slezsku
}

\section{Insight to the windows of medieval and early post-medieval houses in Czech Silesia}

\section{Kateřina Vad'urová}

\begin{abstract}
Abstrakt
Příspěvek pojednává o nálezech středověkého a raně novověkého okenního skla z oblasti českého Slezska. Prezentovány budou především nálezy z archeologických výzkumů středověkého jádra Opavy, ale také z Ostravy, Krnova, slezských hradů a řady církevních staveb. ${ }^{1}$ Významným zdrojem poznání jsou vedle archeologických pramenů dobová vyobrazení a historické písemné prameny, které zaznamenávají aktivity řemeslníků a obchodníků, osvětlují organizaci obchodu se sklem a šíření okenního skla napříč různým sociálním prostředím. V neposlední řadě bylo zkoumáno i chemické složení vybraných okenních skel, které má potenciál odhalit provenienci skel. Podrobněji budou představeny dva zajímavé nálezy, a to vitráže z chrámu sv. Václava u dominikánského kláštera a pravděpodobné doklady sklenářské dílny z Drůbežího Trhu v Opavě.
\end{abstract}

\section{Klíčová slova}

Okenní sklo, vitráže, středověk, raný novověk, Opava, Slezsko

\begin{abstract}
The article deals with the findings of medieval and post-medieval window glass from the Czech Silesia. Findings from archaeological excavations from the historic city center of Opava, but also from Ostrava, Krnov, Silesian castles and a number of church buildings will be presented. In addition to archeological data, historical paintings and written documents are important sources of knowledge, which record the activities of craftsmen and merchants, illuminate the organization of the glass trade and the process of spreading of window glass across wide social strata. The chemical composition of selected window panes was analysed, which has the potential to reveal the provenance of glass products. Two interesting finds will be presented in more detail: stained glass from the Church of St. Wenceslas belonging to the Dominican monastery and remains of a glazier's workshop from the Poultry Market in Opava.
\end{abstract}

\section{Key words}

Window glass, stained glass, Middle Ages, Post-Medieval period, Opava, Silesia 
Okenní sklo je stále ještě opomíjenou skupinou archeologických nálezů, přestože od vrcholného středověku tvořilo významný podíl sklářské produkce. ${ }^{2}$ Okna, jejich uspořádání, velikost a výzdoba, významně ovlivňovala a dotvářela charakter interiérů středověkých a ranně novověkých staveb. To platí dvojnásob pro okenice zasklené různobarevnými tabulkami nebo vitrajemi zdobenými malbou. Zaskleným oknům nelze upřít kromě estetické hodnoty i hodnotu praktickou, čímž je zvýšení komfortu bydlení a více světla v interiéru. Osazovaní okenních otvorů skleněnými tabulemi či terčíky ale nebylo vždy samozřejmostí.

\section{Od antiky po renesanci}

Uzavírání okenních otvorů materiály propouštějícími světlo bylo známo již ve starověkém Řecku, kde byly používány tenké kamenné destičky, olejová plátna nebo vypnuté zvířecí blány. $\mathrm{Z}$ pozdně římského období jsou již doloženy olověné desky s otvory osazenými průsvitnými křemeny, alabastrem nebo kousky skla. Doložena je technika spojování skleněných výplní pomocí olova, která se z Říma rozšíríila i severním směrem (Losos 2006, 10).

Od raného středověku byly k zasklívání oken použivány ploché destičky vyrobené z barevného skla, jež mohly být zdobeny malbou. Tabulové okenní sklo bylo ve středověku vyráběno cylindrickou (válcovou) nebo katedrální metodou. Katedrální metoda spočívala v nalití roztaveného skla na hladkou podkladovou des$\mathrm{ku}$ a rozetření do požadované plochy a tloušt'ky (Cónová - Gajdošová - Lacková 2006, 14). Při výrobě cylindrickou metodou sklář nejdříve vyfoukl baňku skla, ze které pomocí nářadí a hladké podložky vytvořil válec. Ten následně rozstřihl, rozvinul a pomocí nástrojů vyhladil. Vznikla tak obdélná tabule s nerovnými okraji a s nepravidelnou tlouštkou (okraje byly silněj- ší než střed tabule), kterou bylo potřeba dále upravit. $^{3}$

V českých zemích se nejstarší nálezy koncentrují v prostředí církevních staveb na lokalitách centrálního charakteru. Na Moravě to jsou Mikulčice, uhersko-hradištská aglomerace a Olomouc (Bláha 2000; Galuška - Macháček - Pieta - Sedlácková 2012, 88-89; Himmelová 2000, 87), v Čechách především Praha, ale také Stará Boleslav (Boháčová - Frolik - Petřićková - Žegklitz 1990, 178, obr. 1:6; Špaček 2000, obr. 2).

Vitrajová okna sestavená z barevných skleněných segmentů zdobených malbou byla velmi oblíbená až do období pozdního středověku. ${ }^{4}$ Bohužel se do dnešních dob většina vitrají nedochovala. Obraz o jejich kráse si tak můžeme poskládat pouze z drobných úlomků získaných z archeologických výzkumů. V Čechách se gotické vitraje zachovaly spíše ve venkovských kostelech, což svědčí o dostupnosti malovaných okenních skel i v prostředí nižší šlechty. Jako př́klad lze uvést vitraje z kostela sv. Jakuba v Žebnici (Černá 1994 ed., 64; Cílová - Kučerová - Knižová 2013), z Oseku, Úboče a několika kostelů na Domažlicku (Černá 2004, 22; Losos 2006, 20-21).

Paralelně ale byla vedle vitrají používána i bezbarvá tabulová okenní skla a od 14. století i kruhové terčíky, které postupně téměř vytlačily tabulové sklo. Běžně se s nimi setkáváme v archeologických kontextech od konce 14. až do 18. století. Postup výroby okenních terčíků se od tabulového skla liší. Až do 18. století byly vyráběny korunovou technikou, tj. roztáčením skleněné bubliny a jejím zploštěním do disku za pomoci „hladítka“ (napřríklad prkénka). Současně byla používána druhá varianta této techniky, kdy bylo zploštění bubliny dosaženo tak, že na druhý konec bubliny byla přichycena kovová tyč, jež protitlakem pomáhala v jejím roztáčení. Poté byla bublina odříznuta od píštaly a roztočena, čímž došlo k rozvinutí do disku. ${ }^{5}$ Spolu $\mathrm{s}$ terčíky jsou v archeologických situacích často 
nalézány trojúhelníkové výplně se zaštípanými hranami, které vyplňovaly prostory mezi jednotlivými terči. Terčíky a trojúhelníkovité výplně byly spojovány pomocí olověných pásků s profilem ve tvaru „H“.

$\mathrm{V}$ pozdním středověku již mizí vitrajová okna, doložena jsou ale okna složená z nezdobených terčíků či tabulek, případně s centrálním terčíkem zdobeným malbou (Losos 2006, 21). Výrazně ale převládají okna z nezdobených terčíků s přehnutým okrajem, méně s okrajem zataveným. Od 16. století se v archeologických souborech nově setkáváme $\mathrm{s}$ terčíky vyrobenými talířovou metodou. Při tomto postupu byla skleněná bublina pomocí hladítka či rovné plochy z jedné strany stlačena a poté byl vzniklý „talíř“ odříznut od horní části bubliny upevněné k píštale. Tím vznikl terčík bez stop po prrílepníku, ale se stopami po roztáčení. Tento postu výroby okenních terčů je zachycen v Agricolově spise De re metallica, Libri XII (viz Kaufmann 2010, 40-41, abb. 8-9). V období renesance se opět širrí nezdobené sklo tabulové, což dokládá i řada dobových vyobrazení (viz dále).

Kromě archeologických pramenů k poznání historie a vývoje okenního skla přispívají značnou mírou historické písemné zprávy. První písemná zmínka o okenním skle v českých zemích pochází z kroniky sázavského kláštera a hovoří o opatu sázavského kláštera - Reginaldu z Met - a jeho znalostech sklářského řemesla (Tomek ed. 1882, 217). Zasklení oken v chrámu sv. Víta již po polovině 13. století dokládá zmínka z roku 1264 o větrem zničených prostých skleněných oknech (Winter 1906, 81). Tentýž chrám pak biskup Jan III. z Dražic ( $\uparrow 1278)$ vybavil dvěma novými vitrajovými okny s biblickými motivy (Losos 2006, 20). Zřejmě nejznámější zpráva pochází z roku 1451 z pera papežského legáta Enea Silvia Piccolominiho, pozdějšího papeže Pia II., který se ve spisu Historia Bohemica obdivně vyjádřil o okázalosti chrámových oken v Čechách (Kostílková 1999, 95).

\section{Skláři, sklenáři a malíri skla ve Slezsku v písemných a ikonografických pramenech}

Již od raného středověku se v písemných pramenech objevují pojmy vitrearii a vitrifactores, pod kterými se skrývají výrobci a zpracovatelé skla. Mladší označení fenestrarii již signalizuje řemeslníky specializující se na okenní sklo. V období vrcholného středověku jsou skláři a sklenáři označováni jako vitreator, viteator, vithreator nebo německy jako glaser, glasser či glazzer (Sedláčková 2010, 362).

Sklenáři, malíŕi skla a obchodníci se sklem nebyli ve středověku př́liš početnou skupinou. Dokonce ani v největších městech v zemi, jako byla Vratislav (Wrocław), nevytvořili ve 14. ani 15. století nezávislý cech. Sklenáři se proto spojovali do cechů s jinými řemesly, například ve Vratislavi byli připojeni do cechu s tesaři, malíri a zlatníky, ale v nejstarším potvrzení cechových privilegií králem Václavem z roku 1390 nejsou jmenovitě uvedeni. Jmenováni jsou až v roce 1420 , když císař Zikmund potvrdil jejich spojení s výše zmíněnými řemesly. Vlastní cech sklenářu byl vyhlášen až roku 1578 (Czihak 1891, 42). ${ }^{6} \mathrm{Na}$ základě soupisu opavských cechů z roku 1608 víme, že sklenáři zde, spolu s dalšími nepočetnými řemesly, patřili do bratrstva u cechu zámečníků (Matějek 1967, 62). V písemných pramenech se zachovalo jen několik jmen členů cechu sklenářů a malírů skla z konce 15. až počátku 17. století. Podle E. Czihaka je malý počet členů cechu pochopitelný, vezmeme-li $\mathrm{v}$ potaz rozšíření skleněných oken, které - s výjimkou kostelů a radnic - nebylo v soukromých domech vůbec běžné. Údajně ještě v roce 1469 byla okna královského hradu ve Vratislavi opatřena pergamenem, nikoliv sklem (Czihak 1891, 42-43). Archeologické prameny z českého Slezska však vytvářejí odlišný obraz, který ukazuje, že ve 2. polovině 15 . století již byla skleněná okna poměrně běžná v lépe situovaných 
měštanských domech i domech střední řemeslnické vrstvy.

Přestože nám archeologické výzkumy přinášejí stále nové doklady užívání okenního skla již od 14. století, nelze jeho spotřebu ve středověkém Slezsku ani v jednotlivých městech kvantifikovat. Hrubou představu, jak velké množství to muselo být, si lze udělat na základě historických písemných pramenů. Objednávky a dodávky skla zachycené $\mathrm{v}$ těchto zprávách tvoří však pouze zlomek realizovaného obchodu s okenním sklem.

Nejstarší konkrétní zmínka o zasklívání oken ve Slezsku pochází z roku 1333 a váže se k augustiniánskému klášteru v Zaháni (Żagań). Od 14. století v písemných pramenech mezi městskými řemeslníky vystupují také skláři, sklenáři a malíři skla. Výjimečně jsou zaznamenána jména konkrétních sklenářů či malíruo skla působících v zemích Koruny české. V roce 1374 je písemnými prameny doložen prríchod skláře nebo malíre okenního skla Conrada do Lehnice (Legnica). V roce 1394 bylo pak u jistého skláře Konráda objednáno 12 tabulí skla radními z Břehu (Brzeg; Czihak 1891, 5). Obchod s okenním sklem na poměrně velké vzdálenosti dokládá smlouva z roku 1376, kde se sklenář Nicolas Queysser ze Zábřehu na Moravě nebo Sklenařic u Vysokého nad Jizerou zavázal dodat 32 set skla Hanuši z Hlohova (Głogów). Tato objednávka mohla na základě propočtů z mladší doby obsahovat až 2000 kusů skla (Lněničková 2004, 14). Vzhledem k velké spotřebě okenního skla pro církevní stavby lze však předpokládat, že nebyla nijak ojedinělá. Další sklenář je jmenován ve zprávě z roku 1416, podle které malîr Petr dodal kostelu sv. Mikuláše v Břehu malované okenní sklo. Z 18. května 1480 pochází zpráva, podle níž hlohovský kníže Jan ve svém pokoji rozbil okenní tabuli zdobenou motivem Krista na kříži (Czihak 1891, 5).

V písemných pramenech z počátku 17. století je v souvislosti s odvody vrchnosti jmenovitě uvedeno okenní sklo a je zde stanoveno i přesné množství výrobků, které museli skláři odvádět. Například podle záznamu v urbáři panství Branná z roku 1607 měl Kryštof Heusler, hut'mistr stř́ibrnické sklárny, odvádět na den sv. Jiří 30 pivních sklenic a na den sv. Michala 30 bíle pruhovaných vinných sklenic. Na oba dny zároveň odváděl 4 zlaté, 10 kop skleněných koleček (tj. okenní sklo) a dvě pozlacené a malované sklenice s víkem (Štěpán - Štěrbová 1999, 19). V roce 1610 udělil Hynek ml. Bruntálský privilegia k založení sklárny v Malé Moravě Georgu Schürerovi, který měl vrchnosti ročně odevzdat „64 tolarů, 10 kop neprůsvitných okennich koleček, 10 kop koleček do olova, 4 sklenice se znaky vrchnosti, 2 kopy pionich a 2 kopy vinných sklenic" (Štěrbová - Štépán 1999, 20). Hutmistr sklárny v Bílé Vodě, Dominik Schürer, se v roce 1612 zavázal odvádět „puil truhly průsvitných okennich koleček, 1 a půl truhly malých okennich koleček a 5 kop vinných a pivnich sklenic" (Štěpán 2001, 4). Tyto zprávy mimo jiné dokládají, že okenní sklo tvořilo v raném novověku velkou část produkce slezských skláren.

O tom, jak vypadal provoz ve sklenářské dílně v raném novověku, si můžeme udělat představu na základě historických maleb, rytin a jiných dobových vyobrazení. Například v díle Nürnberger Hausbücher jsou na vyobrazeních z roku 1554 a 1613 zachyceni sklenáři sestavující okno z kruhových terčíků (obr. 1-2). ${ }^{7} \mathrm{Na}$ obou malbách jsou na pracovních stolech připraveny nástroje, které sklenáři používali. Sklenář při práci je zobrazen také v díle J. Ammana Eygentliche Beschreibung aller Stände auff Erden, hoher und nidriger, geistlicher und weltticher, aller Künsten, Handwercken und Händeln na vyobrazení z roku 1568 (obr. 3; Amman - Sachs 1568). Další rytina z tohoto díla zachycuje při práci malíře skla. Tato vyobrazení pocházejí až z období renesance, vzhledem k ustálenému tvaru okenních skel a technologii výroby je však lze aplikovat i na starší období. ${ }^{8}$ 


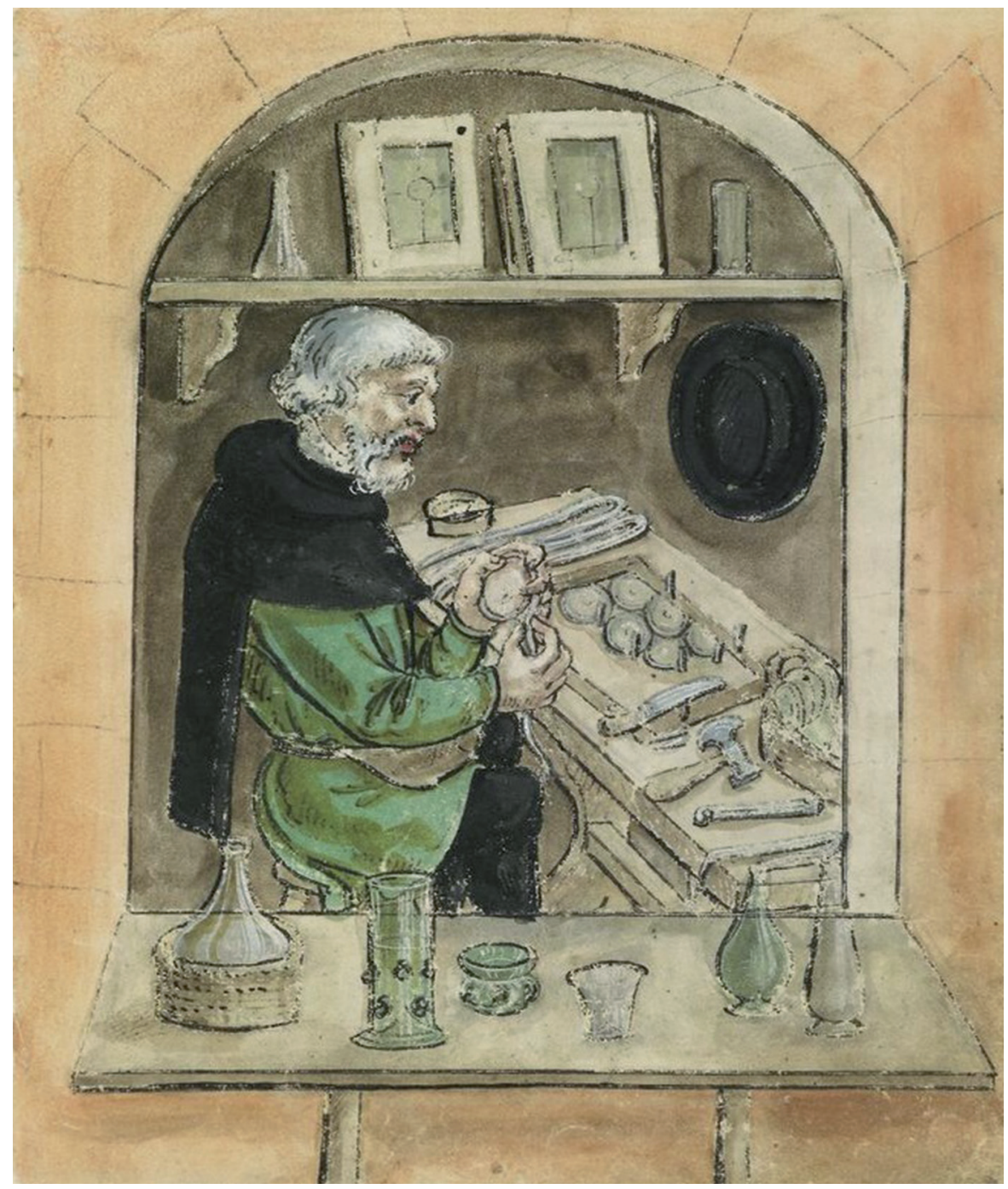

Obr. 1: Sklenář Niclas Klupch při práci, 1554. Nürnberger Hausbücher, Landauer I, Amb. 279.2 , Folio 40. Převzato z: Kaufmann 2010, 44, abb. 11a.

Fig. 1: Glazier Niclas Klupch at work, 1554. Nürnberger Hausbücher, Landauer I, Amb. 279.2 , Folio 40. Borrowed from: Kaufmann 2010, 44, Abb. 11a. 


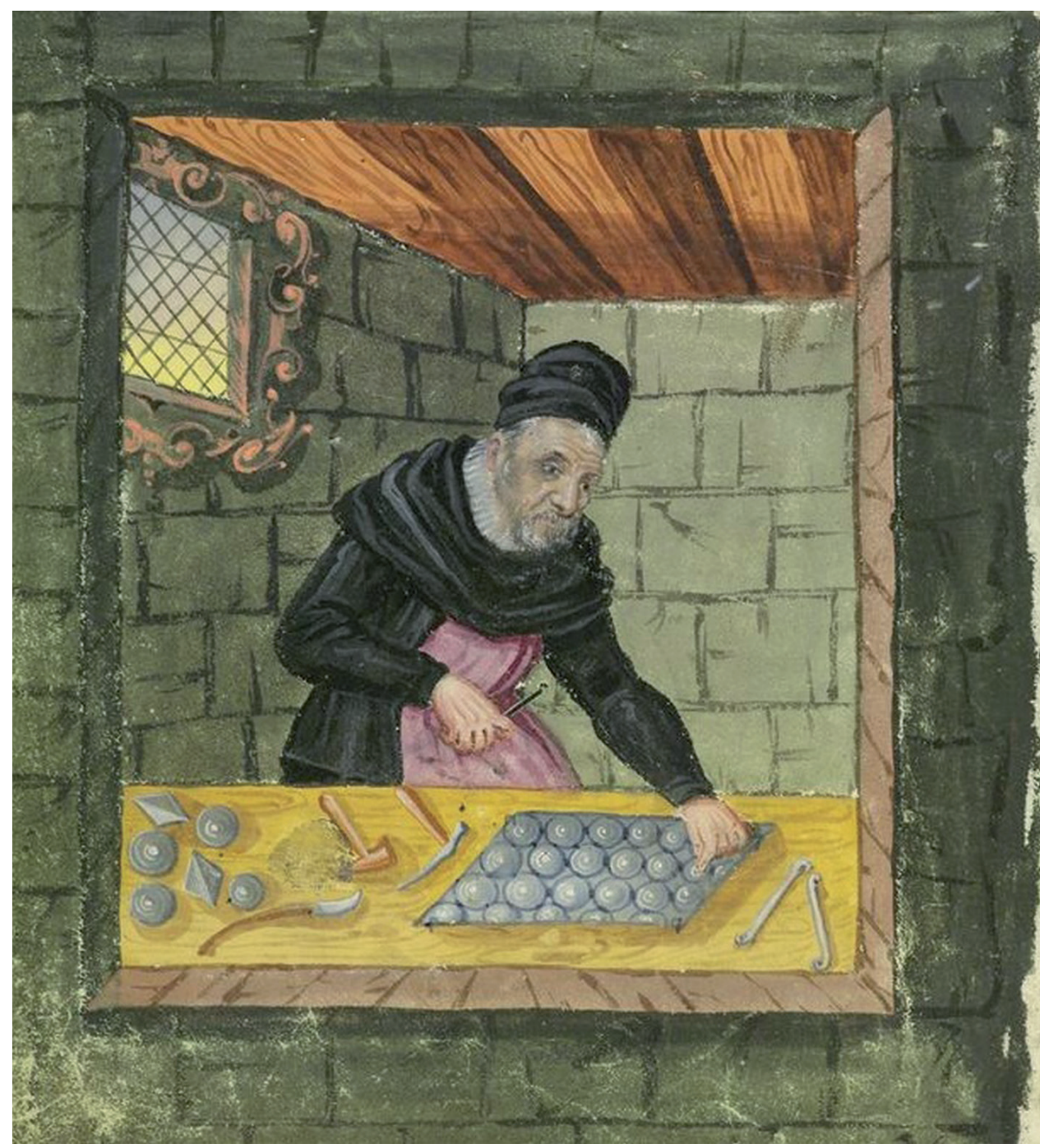

Obr. 2: Sklenář při sestavování okna, 1613. Nürnberger Hausbücher, Landauer l, Amb. $279.2^{\circ}$ Folio 83 recto. Online zdroj: http://www.nuernberger-hausbuecher.de/75-Amb-2-279-83-v/data

Fig. 2: Glazier assembling a window, 1613. Nürnberger Hausbücher, Landauer I, Amb. $279.2^{\circ}$ Folio 83 recto. Online source: http://www.nuernberger-hausbuecher.de/75-Amb-2-279-83-v/data 


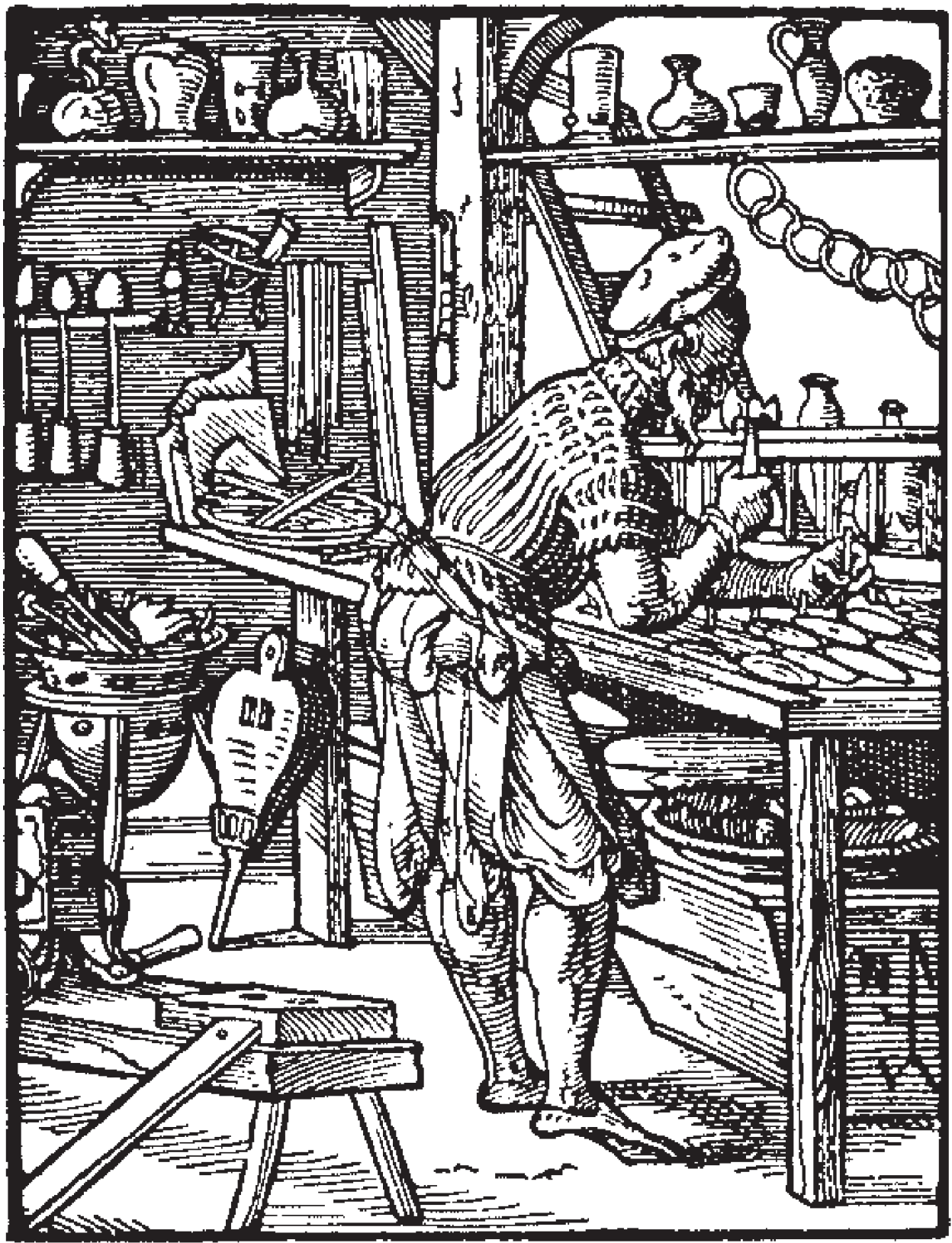

Obr. 3: Sklenář (Der Glasser, Amman - Sachs 1568). Převzato z: Kaufmann 2010, 45, abb. 11b.

Fig. 3: The Glazier (Der Glasser, Amman - Sachs 1568). Borrowed from: Kaufmann 2010, 45, Abb. 11b. 


\section{Ze skláren do domácností - obchodníci se sklem a mechanismy distribuce}

Výrobu okenního skla je možné rozdělit na dvě fáze - primární (zpracování sklářského kmene a výroba okenního skla) a sekundární (malba, sestavování vitráží) - které mohly probíhat na různých místech (sklárny vs města). ${ }^{9}$ Toto rozdělení výroby vedlo $\mathrm{k}$ tomu, že okenní sklo muselo projít rukama několika různých řemeslníků a obchodníků, než se dostalo ke koncovým uživatelům.

Skleněné výrobky se od sklářů k uživatelům mohly dostávat různými způsoby. Jedním z největších odběratelů byli sami zakladatelé skláren, tedy šlechta a církev. Významnými podporovateli sklářství ve Slezsku byly zejména vratislavští biskupové. Mezi sklárny, které založili, patří hutě v Kobylé nad Vidnávkou (založena 1509), Skorošicích (1536) a Nýznerově. Tyto hutě měly tedy zajisté zásobovat sklem především vratislavské biskupství. ${ }^{10}$ Mezi podporovatele sklářství patřil i biskup Karel Ferdinand Vasa, velmistr Řádu německých rytířů, jenž založil v roce 1636 hut v Mnichově (Štěpán 1998, 23). Mezi šlechtická založení patřily sklárny ve Vikanticích (1437), Janušově (1529), ve Sklené (1577) a v Bílé Vodě (1612). Významným podporovatelem sklářství z řad šlechty byl Hynek ml. Bruntálský z Vrbna, který založil sklárny ve Skleném, Nové Senince a Velkém Vrbně (Štěpán - Štěrbová 1999, 20). ${ }^{11}$

Další část produkce byla učena pro místní trh a nadregionální obchod. Pokud byla sklárna v blízkosti města, mohl dodávky skla do města zajištovat sám sklář nebo jeho rodina. ${ }^{12}$ Podle A. Wyrobisze $(1968,173)$ ale skláři, na rozdíl od jiných řemeslníků, své výrobky sami neprodávali. Důvodů bylo hned několik: náročná práce ve sklárně, lokalizace hutí do zalesněných oblastí dál od měst a vzdálenost od významnějších komunikací znemožňovala sklářům organizovat prodej přímo. Proto na scénu vstoupili kupci a obchodníci. Ti ve sklářských hutích nakoupili velké množství skla, jež poté ve dnech trhů dováželi do měst, kde jej nabízeli k prodeji, distribuovali jednotlivým zákazníkům i městským sklenářm (Wyrobisz 1968, 176). ${ }^{13} \mathrm{~S}$ tímto způsobem distribuce ale pro období vrcholného středověku nesouhlasí E. Černá, podle které skláři sami prodávali své výrobky koncovým uživatelům.

Je tedy možné, že i městští sklenáři kupovali skleněné tabule přímo od sklářů provozujících hut např́klad v zalesněných oblastech česko-polského pohraničí. Z okenních tabulí velkých rozměrů sklenář vyštípal tabulky či výplně požadovaných velikostí a tvarů, které pak sám doplnil malbou nebo tímto úkolem pověřil dalšího řemeslníka specializujícího se na malbu skla.

$\mathrm{V}$ případě větších dodávek okenního skla pro církevních stavby bylo toto sklo zřejmě vyráběno na konkrétní objednávku a jeho sekundární zpracování probíhalo pravděpodobně až na místě stavby. V kontrastu k tomuto mechanismu stojí zmínky z období renesance o židovských sklenářích, kteří obcházeli vesnice a vyhledávali zakázky na venkovských sídlech (Lněničková 2004, 15).

O detailnější organizaci obchodu se sklem ve Slezsku toho víme velmi málo, většina zpráv navíc pochází z dnešní polské části Slezska. V Polsku v období středověku ani v raném novověku nejsou doloženi obchodníci specializující se pouze na obchod se sklem. Většinou se kupci zajímali i o jiné obchodní komodity, například o textil, kovové předměty a podobně. Lze předpokládat, že stejně tomu bylo i na území dnešního českého Slezska. Slezští kupci obchodovali vedle skla vyráběného v regionálních sklárnách i se sklem dováženým z Benátek, Německa a Čech. Benátské sklo bylo dováženo do Vratislavi, odkud pak bylo dále distribuováno do Krakowa a Poznani. Právě Polsko bylo ale také významným odbytištěm výrobků českých a slezských skláren. Dovoz skla z Vratislavi, Kladska 
a Nysy do Polska je doložen v celních knihách (Wyrobisz 1968, 185-186). ${ }^{14}$ Součástí těchto dodávek mohlo být vedle regionálních výrobků i sklo cizí provenience.

$\mathrm{V}$ písemných pramenech najdeme i zprávy o obchodu se sklem na regionální úrovni. Sklářský mistr Michal Schiritz ze sklárny Sklená u Pustých Žibřidovic ${ }^{15}$ byl ve spojení s obchodníkem Kryštofem Veylem z Vratislavi, kam zřejmě míriily luxusnější výrobky této sklárny (Štěpán Štěrbová 2001, 235). Dalším dokladem obchodu se sklem ze slezských skláren je záznam z mýtního rejstř́iku Zlatých Hor z listopadu roku 1605, kdy obchodník Jiří Nentwig, který působil ve Slezsku, převážel přes zlatohorské mýto jeden vůz skla (Štěpán 2006, 47; Šrámková 2012, 29). V již tak skromných písemných pramenech ale často není specifikováno, zda se jedná o okenní nebo duté sklo.

\section{Nejstarší okenní sklo - 13. století - 1. polovina 14. století}

V českém Slezsku a na severní Moravě bylo středověké a raně novověké okenní sklo nalezeno na lokalitách různého charakteru. Přestože by se po vynesení lokalit do mapy (obr. 4) mohlo zdát, že nejpočetněji jsou mezi lokalitami zastoupena šlechtická sídla, nejvíce materiálu pochází z městského prostředí, především z Opavy, což je do jisté míry způsobeno stavem výzkumu.

Nejstarší nálezy středověkého okenního skla v českém Slezsku se podobně jako na Moravě a v Čechách koncentrují v prostředí církevních staveb, kde jsou doloženy již od 13. století. ${ }^{16} \mathrm{Ve}$ středověké sakrální architektuře hrálo významnou roli světlo, proto byl velký důraz kladen na osvětlení interiéru kostelů a s tím související vzhled chrámových oken (jejich architektonické členění a ornamentální uspořádání). Paprsky světla prostupující barevnými vitrážemi zvýraz- ňovaly monumentalitu chrámů a měly ve věřících zanechat silný dojem.

V tomto období je okenní sklo v archeologických situacích zastoupeno především fragmenty silně zkorodovaných okenních tabulek, které jsou pozůstatkem vitrajových oken. Výroba středověkých vitrají představuje komplexní, umělecky i technicky náročný proces. Sklář musel nejprve vyrobit několik různě barevných tabulí skla, z nichž byly podle připraveného nákresu vyřezány segmenty požadovaných tvarů tak, aby tvořily základní motiv. Tato základní kompozice byla poté v detailech doplněna malbou, po jejímž vypálení byly jednotlivé díly spojeny olověnými pásky. Pásky nejen oddělovaly jednotlivé barvy skla, ale zároveň tvořily i obrysy postav a motivů.

Po celé období gotiky byla rozšířenou technikou výzdoby okenního skla konturová malba prováděná konturovou černí. Tento styl malby byl použit také na nálezech vitrají z Opavy a Bohušova. Příprava barvy byla poměrně složitá. Základní složkou byla směs rozdrceného skla s přídavkem oxidu olovnatého a barviv, která byla roztavena a následně znovu rozdrcena. Vzniklý pigment byl smíchán s pojidly (například ocet, olej), aby bylo možné jej snadněji nanášet štětcem (Losos 2006, 70-71). ${ }^{17}$ Malba na sklo bez použití šablon vyžadovala zručnost a značný talent. Z písemných pramenů víme, že v českých zemích byla od 14. století zakládána bratrstva řemeslníků, v nichž se profese sklenářů často spojovala s malíŕi (Losos 2006, 26). ${ }^{18}$

Ve Slezsku jsou vitrajová okna doložena již ve 12. století ve Vratislavi (Wyrobisz 1968, 108). Zajímavý soubor vitráží pochází z 1. poloviny 13. století z Dómského ostrova ve Vratislavi (Siemianowska 2013). Původní interpretace tohoto hromadného nálezu okenního skla, zlomků nádob a skleněných ozdobných předmětů jako dokladů výroby a zpracování skla na této lokalitě ale byla vyloučena (Pankiewicz - Siemianowska - Sadowski 2018, 49, ryc. 6-12). Důvodem bylo rozmanité 


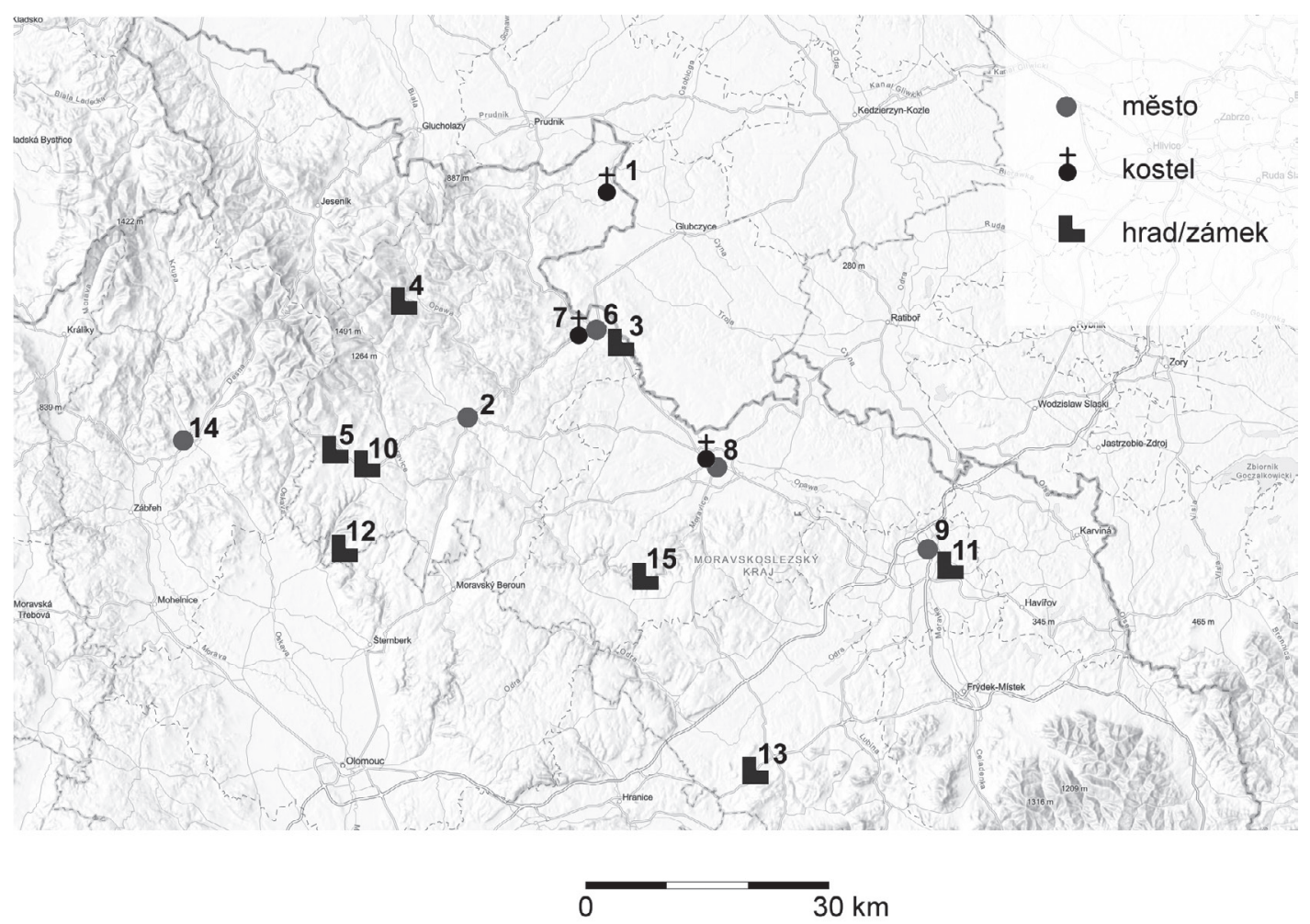

Obr. 4: Lokality s nálezy středověkého a raně novověkého okenního skla v českém Slezsku a na severní Moravě.

1 - Bohušov; 2 - Bruntál, 3 - Cvilín u Krnova; 4 - Fürstenwalde u Vrbna pod Pradědem; 5 - Janovice; 6 - Krnov;

7 - Krnov-Kostelec; 8 - Opava; 9 - Ostrava; 10 - Rýmařov; 11 - Slezskoostravský hrad; 12 - Sovinec; 13 - Starý Jičín; 14 - Šumperk; 15 - Vikštejn.

Fig. 4: Sites with finds of medieval and early modern window glass in Czech Silesia and Northern Moravia.

1 - Bohušov; 2 - Bruntál, 3 - Cvilín u Krnova; 4 - Fürstenwalde at Vrbno pod Pradědem; 5 - Janovice;

6 - Krnov; 7 - Krnov-Kostelec; 8 - Opava; 9 - Ostrava; 10 - Rýmařov; 11 - Silesian Ostrava Castle;

12 - Sovinec; 13 - Starý Jičín; 14 - Šumperk; 15 - Vikštejn.

chemické složení vitráží, které lze rozdělit do ně- bor okenního skla pochází z kostela sv. Martina kolika základních skupin. Převládají skla drasel- v Bohušově. V sakristii kostela, ve vrstvě vzniklé no-vápenatá s různým poměrem $\mathrm{CaO} / \mathrm{K}_{2} \mathrm{O}$, ale v letech 1476 až 1486, bylo nalezeno přes 100 zastoupena jsou i skla s vysokým obsahem olova. zlomků středověkého okenního skla. ${ }^{20}$ Kromě

Existenci vitrají v chrámech v českém Slez- jednoho fragmentu terčíku pocházejí všechny sku dokládají nálezy ze 13. století z Bohušova zlomky z tabulového skla a lze je datovat do a z Krnova-Kostelce. ${ }^{19} \mathrm{~V}$ kostele sv. Benedikta doby výstavby kostela po roce 1275 (obr. 6: v Krnově-Kostelci byl ve vrstvě s. j. 111 z obdo- 14-15; Sedláčková 2011b, 292-294). Šest výplní bí před polovinou 13. století nalezen fragment zdobených malbou rostlinným a geometrickým zkorodované okenní tabulky s ovaleným okra- motivem bylo vyrobeno ze smaragdově zelenéjem (Sedlácková 2009, 172-173). Početnější sou- ho skla. Analýza jedné z nich prokázala drasel- 
no-křemičito-olovnaté složení skla zabarveného mědí (Sedláčková 2011b, 294, 303). Okenní tabulky z olovnatého skla byly v českých zemích používány zejména v období 13. až 1 . poloviny 14. století, což koresponduje s doklady výroby olovnatých okenních skel na území dnešního Německa. ${ }^{21}$ Dalších 99 zlomků tabulek bylo silně postiženo korozí, u řady z nich se ale zachovalo skelné jádro. Tabulky, u kterých bylo možné určit původní barvu, byly vyrobeny ze skla bezbarvého, světle zeleného, žlutohnědého (jantarového) a světle fialového. Mezi fragmenty jsou výplně různých tvarů se zaštípanými hranami i se zatavenými oblými hranami, ojediněle jsou tabulky zdobeny malbou. $\mathrm{V}$ př́padě tabulek z jantarového skla se podařilo identifikovat páskové výplně s motivem perlovce (Sedláčková 2011b, obr. 138: 4-9). Analýzy dvou tabulek ze světle zeleného a jedné $\mathrm{z}$ jantarového skla odhalily draselné složení starobylého původu (Sedláčková 2011b, 303, prríl. A4-A6).

Nálezy z kostela sv. Benedikta patří mezi jedny z nejstarších vitrají na Moravě a v českém Slezsku. Na Moravě jsou ve 2 . polovině 13 . století vitrajová okna doložena pouze $\mathrm{v}$ minoritském klášteře v Brně a v Olomouci. Zlomky bezbarvých okenních tabulek však byly nalezeny i na šlechtických sídlech, například na Kulatém kupci, Smilově hradisku (Sedlácková ed. 2019a, 33; 2019b, 474, 480-484) a ve Veselí nad Moravou (Sedláčková - Rohanová 2015, 312-313). V Čechách je okenní sklo ve 13. století doloženo v blízkosti církevních staveb například v Praze, Chebu, Duchcově a na hradě Borschengrün na Chebsku. V menší míře se již v 13. a 1. polovině 14. století objevuje okenní sklo také v měštanském prostředí, jak dokládají nálezy z Brna-Panenské ulice a Mečové 2 (Sedláčková 2012, 145, obr. 10:6-7; Sedláčková ed. 2019b, 474). V Čechách jsou nálezy okenních skel z běžných sídlištních situací vzácné, ve 13. století jsou doloženy pouze z Prahy a Starého Mýta, více se širrí až ve 14. století (Černá 2004, 23).
Užívání okenního skla v měštanském prostředí již ve 13. století dokládají nálezy barevných i bezbarvých tabulek z Opavy. Ze 2. poloviny 13. století pocházejí zlomky importovaných bezbarvých tabulek nalezených na Dolním náměstí a Drůbežím Trhu (Sedláčková 2011a, 769, 775; 2011b, 299). ${ }^{22}$ Na jedné z tabulek z Drůbežího Trhu jsou na obou delších stranách patrné stopy po řezání a jedna hrana je jemně zaštípaná. Kromě kvalitního bezbarvého tabulového skla byl v jímce 570 na téže lokalitě nalezen zlomek zkorodované okenní tabulky. Také z Dolního náměstí byl získán drobný fragment tabulky se zataveným okrajem ze zkorodovaného druhotně opakního skla.

Do 13. až poloviny 14. století lze klást původ okenní tabulky ze smaragdově zeleného skla, která byla nalezena na Pekařské ulici. ${ }^{23}$ Fragment další vitraje se zaštípanými hranami ze stejně zbarveného skla, navíc zdobené malbou švarclotem, ${ }^{24}$ byl nalezen nedaleko, při výzkumu ve vnitrobloku mezi Horním náměstím a ulicemi Pekařskou a Kolářskou (obr. 6: 13; Břečková 2017, 271, 278, obr. 12). Tabulka pochází z jímky 508 zaplňované v závěru 14. a v průběhu 15 . století. Tato datace může být ale kvůli dlouhé životnosti okenního skla velmi vzdálená době výroby vitraje. Na základě smaragdově zeleného zbarvení lze předpokládat olovnaté složení skla, ale vyloučit nelze ani draselno-vápenaté složení.

\section{Vitráže z kostela sv. Václava u dominikánského kláštera}

V roce 1291 byl přemyslovským knížetem Mikulášem Opavským v poloze u severní části opavských hradeb mezi ulicí Pekařskou, Mnišskou a Solnou založen klášter žebravého řádu dominikánů. ${ }^{25}$ První písemná zpráva o klášteru pochází z let 1303 nebo 1304 z díla francouzského dominikána a inkvizitora Bernarda de Gui (Foltýn a kol. 2005, 538). V roce 1336 byl 
kostel sv. Václava vysvěcen olomouckým biskupem Janem Volkem a ve své době byl největším chrámem v Opavě (Štěpán 2014, 26-27). Během své existence byl klášter i s kostelem několikrát výrazně přestavěn a postihly ho četné pohromy. Kromě důsledků několika požárů se opavští dominikáni museli potýkat s morovou epidemií, reformačním hnutím, majetkovými problémy a nepřízní opavských měštanů. V roce 1786 byl pak klášter zrušen. ${ }^{26}$

V 60. až 80. letech minulého století provádělo Slezské zemské muzeum v prostoru dominikánského kláštera a k němu náležejícího kostela sv. Václava záchranný archeologický výzkum v několika etapách. Výzkumy byly zahájeny v roce 1967 v souvislosti s přípravami rozsáhlých oprav bývalého kláštera a adaptací na Dům umění (Šikulová 1968, 108). Z prostoru kostela byl kromě jiného materiálu získán unikátní soubor středověkého okenního skla čítající přes 400 zlomků různobarevných vitrají. Na některých tabulkách je i přes silné rozesklení stále patrná původní konturová malba. Část okenních tabulek byla poškozena žárem zřejmě při jednom z požárů, které postihly dominikánský klášter. ${ }^{27}$

Několik desítek až stovek okenních výplní bylo v roce 1987 nalezeno v kapli (sakristii) na jižní straně presbytáře kostela sv. Václava. Přestože jsou tabulky silně zkorodované, podařilo se v několika případech určit původní zbarvení skla. Zastoupeno bylo převážně sklo tmavě zelené, nazelenalé, jantarově žluté, hnědé, bezbarvé, ale také sytě fialové a tmavě modré. Některé z tabulek jsou výrazně silnostěnné. Další zlomky okenních tabulek se zkorodovaným povrchem byly získány z vrstvy uhlíků podél jižní zdi presbytáře. U některých bylo možné i přes poškození korozí identifikovat původní zaštípané hrany.

Dalších 74 zlomků různobarevných okenních výplní bylo získáno z jemné hnědé vrstvy pod uhlíky. Bohužel tyto zlomky byly neodborně očištěny a zakonzervovány, čímž došlo k nenávratnému poškození. Stejně tomu bylo i v případě ca 60 fragmentů okenních výplní nalezených ve výplni jámy při jižní zdi presbytáře. Při ošetření těchto nálezů byly odstraněny korozní vrstvy, čímž došlo k výraznému úbytku hmoty skla a k naprosté ztrátě informací o malbě či o technikách úpravy okrajů vitrají. Díky odstranění zkorodovaných povrchových vrstev lze ale na takto „ošetřených“ fragmentech dobře demonstrovat barevné spektrum okenního skla (obr. 5).

Okenní tabulky zdobené malbou konturovou černí a zhruba 90 zlomků nezdobených tabulek bylo nalezeno v sypké popelovité vrstvě nad maltovou sutí. Mezi zdobenými tabulkami jsou zastoupeny dva kusy smaragdově zelené s malbou v podobě rostlinných motivů (obr. 6: 1, 9), jedna jantarově-hnědá (obr. 6: 12), jedna bezbarvá (obr. 6: 4) a další čtyři kusy, u nichž nelze určit původní barvu skla (obr. 6: 2, 3, 5-8, $10,11)$.

Kvůli velké fragmentárnosti nálezů a odstranění zkorodované povrchové vrstvy části skel nelze určit původní kompozici oken kostela sv. Václava. Pouze v několika případech bylo možné identifikovat rostlinné ornamenty, které zřejmě tvořily pozadí hlavního figurálního motivu, jako je tomu v případě vitrají s motivem sv. Pavla z kostela sv. Prokopa v Nadslavi nebo vitrají z kláštera v Oseku (Losos 2006, barevná příloha mezi s. 36-37). V obou př́padech pozorujeme i shodnou barevnou kompozici okenního skla - modrá, tmavě zelená, světle zelená, žlutá, bezbarvá i fialová. V kostele sv. Václava však nebylo nalezeno okenní sklo červené barvy, což ale může být způsobeno nemožností odhalit původní zbarvení u všech nálezů.

Fragmenty nalezených okenních skel pocházejí z původních středověkých chrámových oken tohoto kostela. Lze předpokládat, že okna kostela sv. Václava byla zasklena již při dostavbě kostela v 1. polovině 14 . století. Přesnou dobu výroby okenního skla z dominikánského kláštera ale není možné určit. Pozůstatkem nejstar- 


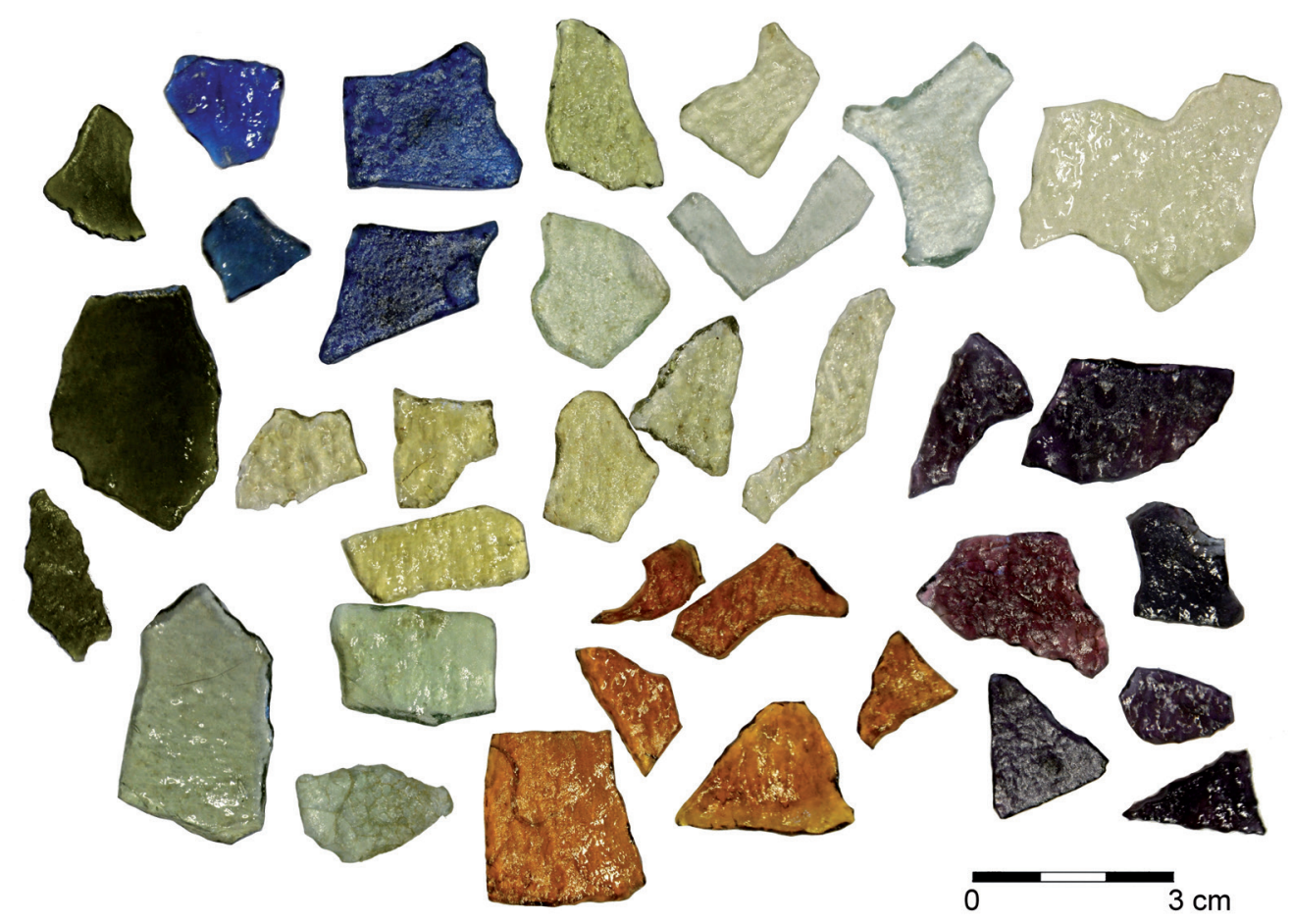

Obr. 5: Barevné spektrum vitrají z kostela sv. Václava v Opavě. SZM.

Foto: K. Vad'urová.

Fig. 5: Colour spectrum of stained glass from the St. Wenceslas Church in Opava. Silesian Museum. Photo: K. Vad'urová.

ších chrámových oken jsou jistě různobarevné vitraje nalezené při jižní zdi presbytáře. $\mathrm{Z}$ těchto nálezů bylo vybráno pět vzorků, u nichž bylo zkoumáno prvkové složení skel - zlomek tabulky ze skla jantarové barvy, velmi lehce nazelenalé, zelené, fialové a smaragdově zelené s malbou švarclotem (tab. 1). Analýzy ukázaly, že tyto vitraje jsou vyrobeny ze skla draselno-vápenatého s nízkým obsahem $\mathrm{SiO}_{2}$ (kolem $50 \mathrm{hm} \%$ ), zatímco obsah alkalických složek $\mathrm{K}_{2} \mathrm{O}$ a $\mathrm{CaO}$ je velmi vysoký.

Tato okenní skla pocházejí z jednoho výrobního okruhu nebo jedné výrobní technologie a podle K. H. Wedepohla patří do skupiny skel tzv. wood-ash glass vyráběných v Německu mezi lety 1000-1400 (Wedepohl - Simon 2010). Podle D. Rohanové byla skla vyrobena z písku nebo oblázků, z bukového popela a pravděpodobně kapradí, které má vysoký obsah $\mathrm{K}_{2} \mathrm{O}$ i $\mathrm{P}_{2} \mathrm{O}_{5}{ }^{28}$ Do stejné skupiny draselno-vápenatých skel patři okenní tabulka ze smaragdově zeleného skla s malbou, u něhož na základě analogií například z kostela v Bohušově (Sedláčková 2011b, 303) bylo mylně předpokládáno olovnaté složení. ${ }^{29}$

Kvantitativně srovnatelný soubor vitrají pochází z biskupského hradu Melice na Vyškovsku, který byl v roce 1423 zničen husity (Vondroušková 2010). Na lokalitě bylo nalezeno přes 370 fragmentů barevných okenních tabulek, 

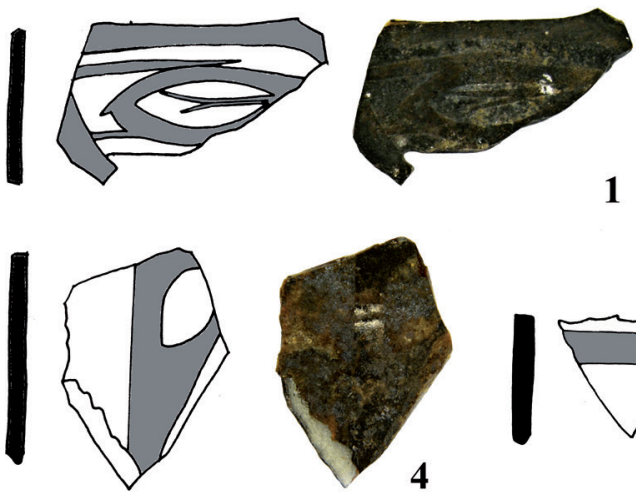

4
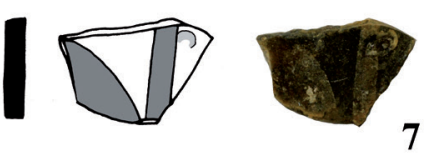

7

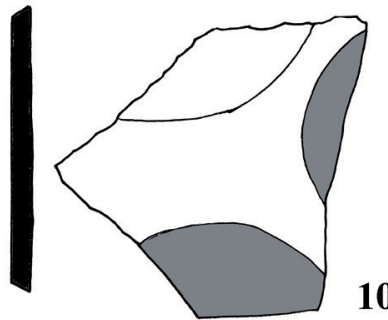

10
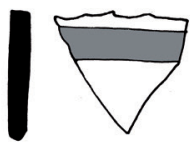

5
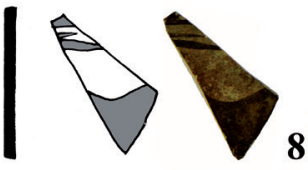

8

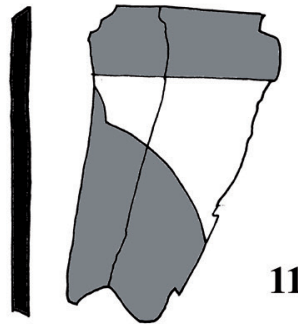

11

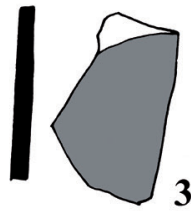

2
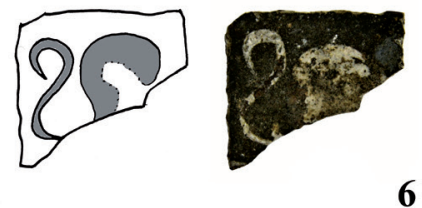

6

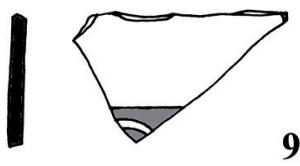

9

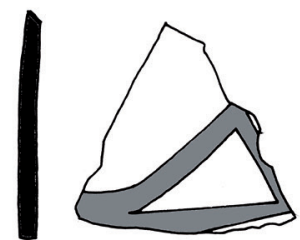

12

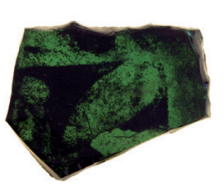

13

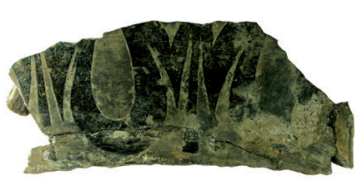

14

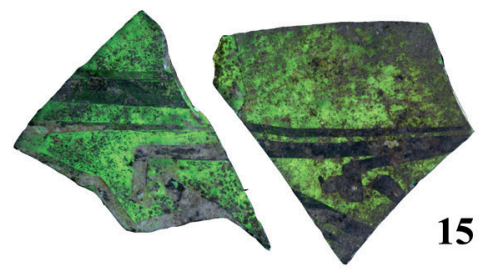

15

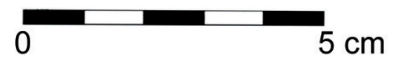

Obr. 6: Zlomky okenních tabulek zdobených malbou. 1-12 - Opava, Dominikánský klášter (1, 9 - smaragdově zelené, 4 - bezbarvá, 12 - hnědá); 13 - Opava, Pekařská-Kolářská; 14-15 - Bohušov (podle Sedláčková 2011b, obr. 4a). SZM (1-12) a NPÚ, ÚOP v Ostravě (13-15). Kresba a foto: K. Vad'urová (1-13).

Fig. 6: Fragments of painted windowpanes. 1-12 - Opava, Dominican Monastery (1, 9 - emerald green, 4 colourless, 12 - brown); 13 - Opava, Pekařská-Kolářská; 14-15 - Bohušov (after Sedláčková 2011b, obr. 4a). Silesian Museum (1-12) and National Heritage Institute, regional branch Ostrava (13-15). Drawing and photo: K. Vad'urová (1-13). 


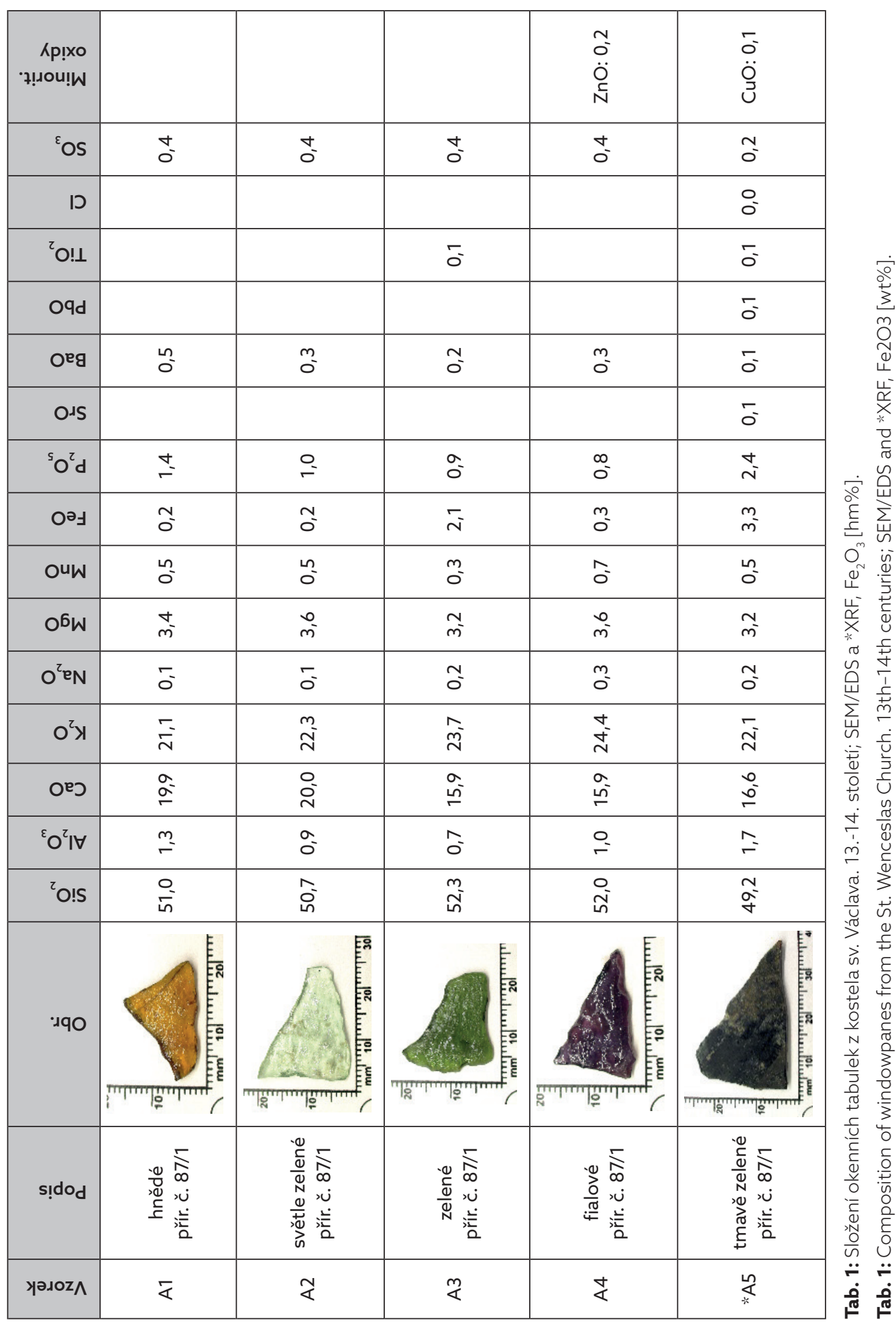


z nichž 178 bylo zdobených malbou. Převládaly fragmenty s rostlinnými motivy nebo černými liniemi.

\section{Šíření okenního skla a proměny sortimentu: 2. polovina 14. století - 1. polovina 16. století}

Kromě množství okenního skla z regionálních skláren bylo podle písemných zpráv do českého Slezska ještě v 15. století dováženo benátské okenní sklo. Sklo regionální provenience (tzv. lesní sklo) ${ }^{30}$ bylo podle stavebních účtů z 15 . století použito například k zasklení oken kláštera sv. Vojtěcha ve Vratislavi (Czihak 1891, 4).

V tomto období jsou doloženy dva základní typy okenního skla. Od poloviny 14. století se vedle tabulového skla stále častěji objevují okenní terčíky s přehnutým okrajem, později s jednoduchým zataveným okrajem, které se udržují i v průběhu renesance. Spolu s terčíky se v archeologických kontextech objevují trojúhelníkové výplně se zaštípanými hranami. ${ }^{31}$ Archeologické nálezy dokládají, že v tomto období zasklívání oken měštanských domů v českém Slezsku již patřilo k poměrně běžné praxi, alespoň ve větších městech. Okenní sklo je ale doloženo také v Ostravě a na některých slezských hradech. Vzhledem k velkému množství materiálu z archeologických výzkumů není možné zahrnout zde všechny nálezy, proto budou představeny pouze vybrané nálezy s dobrou vypovídací hodnotou.

Početný soubor okenního skla byl získán z odpadní jímky 505 na Drůbežím Trhu v Opavě, která byla zaplňovaná od přelomu 14./15. století a v 1. polovině 15. století (Vad’urová 2021, v tisku). Jímka obsahovala několik stovek drobných fragmentů okenních tabulí z nazelenalého skla, z nichž některé byly silně poškozeny korozí. ${ }^{32}$ Tyto zlomky byly identifikovány jako odpad po úpravě a zpracování okenního skla (viz dále:
Sklenář na Drůbežím Trhu). Spolu s tabulkami bylo v objektu nalezeno několik zlomků zkorodovaných terčík $\mathrm{s}$ jednoduchými zatavenými i přehnutými okraji, segment vitraje se zaštípanými hranami zdobené černou konturovou malbou (obr. 7) a několik dalších drobných zkorodovaných fragmentů vitrají.

Zlomek další okenní tabulky zdobené malbou byl nalezen ve vnitrobloku mezi ulicí Mnišskou a Mezi Trhy. Jeho drobné rozměry bohužel nedovolují rekonstruovat původní motiv. Spolu s ním byly v sondě S1 a S2 nalezeny zlomky terčíků s přehnutým okrajem (Břečková 2017, 267). Ze středověku pochází i fragment zkorodované okenní tabulky z Krnovské ulice v Opavě, ${ }^{33}$ na jejímž povrchu se nacházejí zbytky silně poškozené malby. Nicméně nález okenního skla zdobeného malbou svědčí o vyšším společenském postavení majitelů těchto domů. Další tabulky pocházejí z blíže nedatovaných vrstev. ${ }^{34}$ Fragmenty zkorodovaného tabulového skla byly nalezeny např́klad při výzkumu budovy Ostravského muzea v roce 2004 a na Kostelním náměstí v Ostravě. ${ }^{35}$

V období 2. poloviny 14. a 1 . poloviny 15 . století byly vedle tabulového skla paralelně používány okenní terčíky s různou úpravou okrajů (s jednoduchým zataveným, přehnutým nebo zaštípaným), jak dokládají nálezy z Opavy. Kromě již výše uvedených terčíků z Drůbežího Trhu a Mnišské-Mezi Trhy je tento typ okenního skla doložen na dalších lokalitách v historickém centru Opavy. Ze 14. století pochází fragment střední části terčíku vyrobeného z čirého bezbarvého skla, který byl získán z objektu 11 na Kolářské ulici (Sedláčková 2004a, 235). Jediným zlomkem je okenní sklo zastoupeno v odpadní jímce 5 na Masařské ulici 6 - jedná se o fragment terčíku se zaštípaným okrajem o průměru 140-150 mm (Břečková 2017, 262).

$\mathrm{V}$ průběhu 15. století významně vzrostl počet okenního skla, výrazně ale ubylo tabulového skla, které téměř vytlačily okenní terčíky. Zlom- 


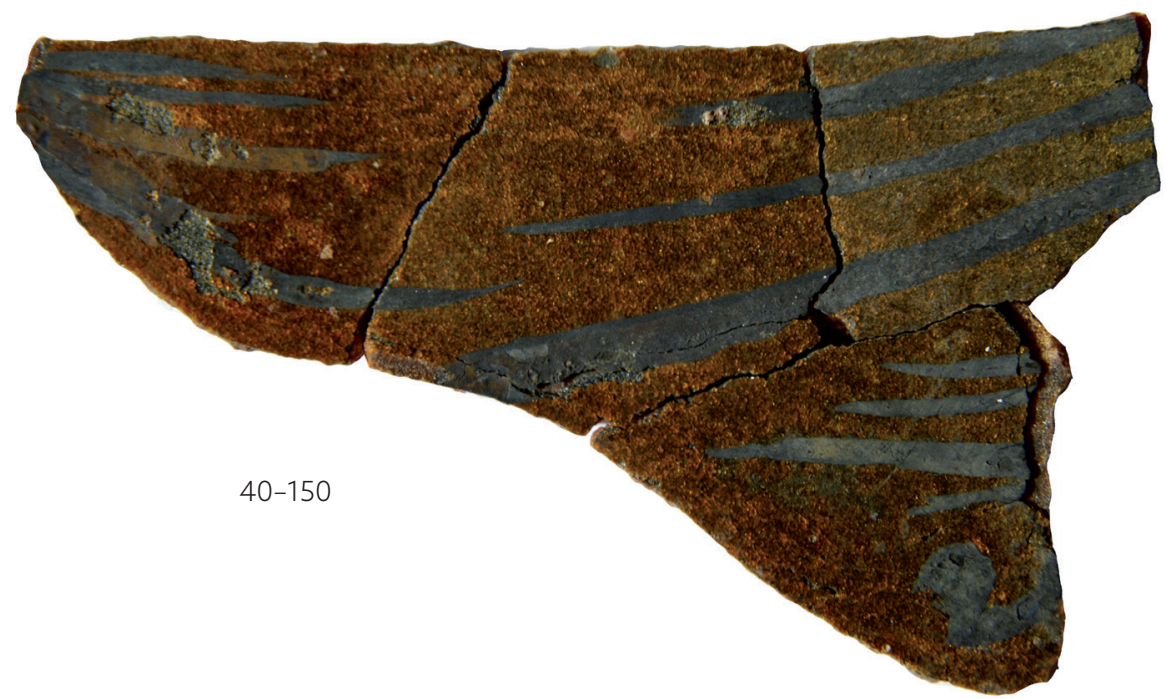

Obr. 7: Tabulka zdobená malbou, Opava-Drůbeží Trh, obj. 505. NPÚ, ÚOP v Ostravě. Foto: K. Vad'urová.

Fig. 7: Painted windowpane, Opava-Drůbeží Trh, Feature 505. National Heritage Institute, regional branch Ostrava. Photo: K. Vad'urová.

ky několika terčíků s přehnutým okrajem byly nalezeny na Drůbežím Trhu v jímce 510 datované do 15. století, s přesahem do 16 . století. Terčíky jsou vyrobeny ze skla bezbarvého, nazelenalého nebo zcela zkorodovaného. ${ }^{36}$ Okenní terčíky s jednoduchým zataveným okrajem jsou doloženy v odpadní jímce 500 na Drůbežím Trhu využívané v průběhu 15 . a 16. století. V téže jímce byl nalezen i téměř celý terčík $\mathrm{s}$ přehnutým okrajem z velmi lehce nazelenalého skla a střední část terčíku z téměř bezbarvého skla.

Zasklená okna měly také domy na Kolářské ulici, jak dokládají nálezy ze středověkých odpadních jímek zachycených při výzkumech v 60. letech. Zlomky středních částí několika okenních terčíků byly nalezeny v jímce 3/60, která obsahovala materiál ze 14 . až 15 . století (Sedláčková 2004a, 226). Z další jímky 11/63 byl získán pouze jeden zlomek střední části terčíku z bezbarvého skla (Sedlácková 2004a, 235). Čet- né fragmenty okenního skla ale pocházejí z odpadní jímky 12/63, která byla zaplňovaná od konce 15. a v průběhu 16. století. Jímka vedle dutého skla obsahovala okenní výplně ve tvaru trojúhelníčků a obdélníků vyštípané z terčíků, terčíky s přehnutými okraji a fragmenty olověných rámečků. Terčíky byly vyrobeny z velmi lehce nazelenalého až našedlého skla a mají průměr 93-98 mm (Sedlácková 2004a, 237, obr. 9). Okenní sklo se do jímky dostalo pravděpodobně v souvislosti se stavebními úpravami domu, $\mathrm{k}$ němuž odpadní jímka náležela.

O vzhledu oken opavských domů ve 2 . polovině 15 . století si můžeme udělat představu na základě nálezů z vnitrobloku Horní náměstí-Pekařská-Kolářská (obr. 8). V zadních částech parcel náležejících $\mathrm{k}$ domům na severní linii Horního náměstí bylo odkryto několik středověkých odpadních jímek. ${ }^{37} \mathrm{~V}$ jímce 508 zaplňované od konce 14. a v průběhu 15. století bylo nalezeno nejméně 30 okenních terčík hladkých i zdobených 


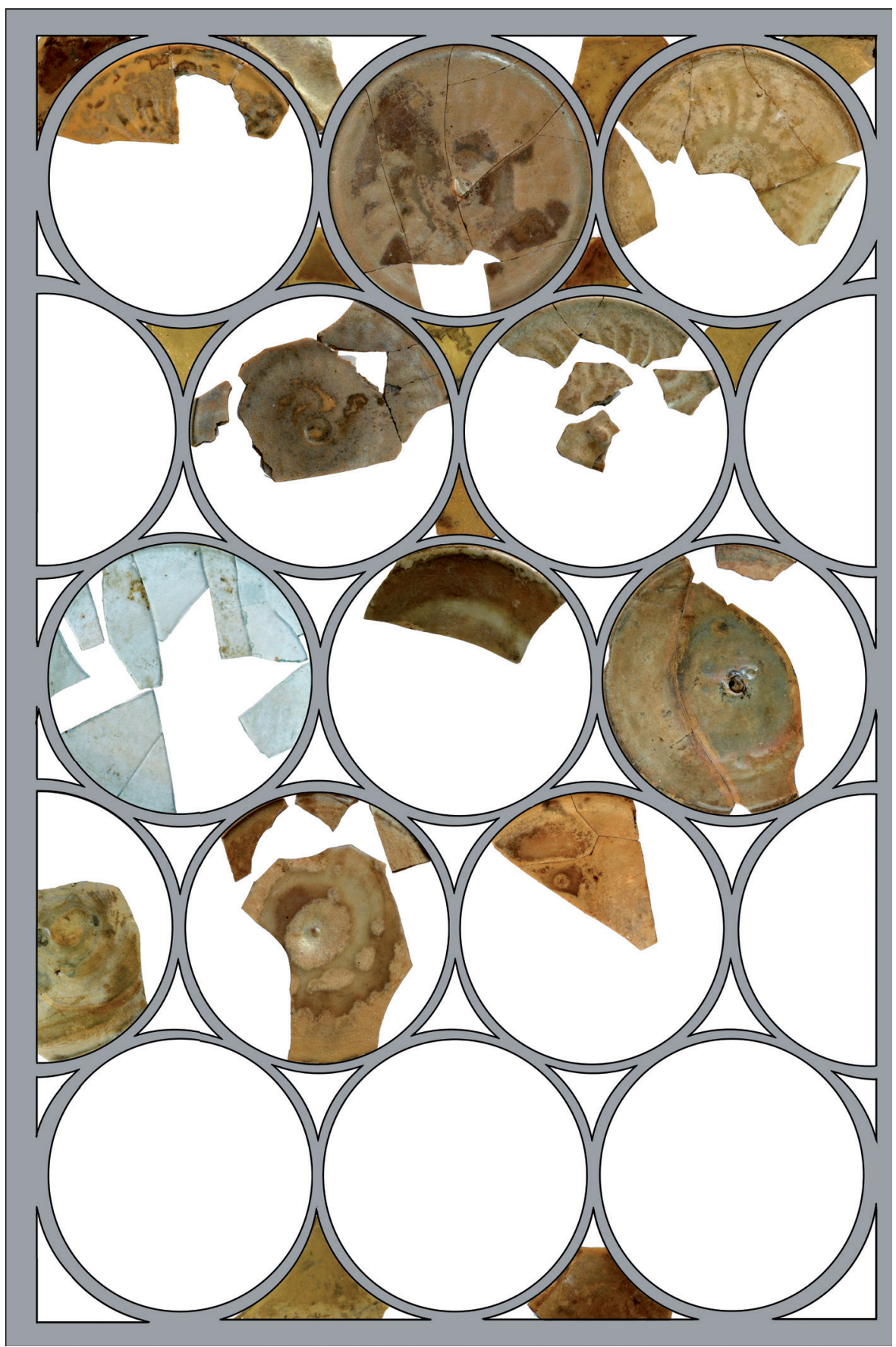

Obr. 8: Rekonstrukce okna na základě nálezů z odpadní jímky 508 ve vnitrobloku mezi Horním náměstím, Pekařskou a Kolářskou ulicí. NPÚ, ÚOP v Ostravě. Autor: K. Vad'urová.

Fig. 8: Window reconstruction based on finds from cesspit 508 inside the block of houses between Horní náměstí square, Pekařská and Kolářská streets. National Heritage Institute, regional branch Ostrava. Author: K. Vad'urová. 
optickým dekorem, již dříve zmíněná tabulka ze smaragdově zeleného skla a 55 trojúhelníkových výplní se zaštípanými hranami, a to jak rohových, okrajových, tak i výplní ze středních částí okenic (Břčková 2017, 270-271). Vzhledem k velké fragmentárnosti nálezů nelze určit přesný poměr zdobených a nezdobených terčíků, převažovaly však terčíky hladké. Obě varianty jsou doloženy s přehnutými i jednoduchými zatavenými okraji. Jejich průměr se pohyboval $\mathrm{v}$ rozmezí 135-150 $\mathrm{mm} \cdot{ }^{38}$ Některé z nich byly záměrně rozpůleny (či jinak ořezány), aby mohly být osazeny po stranách oken. ${ }^{39}$

Okenní terčíky s optickým dekorem, který vznikl předfouknutím baňky skla do kovové nebo dřevěné formy, představují novinku - v archeologických souborech se objevují od 2. poloviny 15. století. V českém Slezsku jsou terčíky s optickým dekorem doloženy sporadicky. Ve všech případech se jedná o exempláře zdobené jemnými žebry stáčejícími se od okraje směrem ke středu terčíku. Kromě již zmiňovaných nálezů z odpadní jímky 508 na Horním náměstí-Pekařské-Kolářské byly terčíky s optickým dekorem nalezeny mezi ulicí Mnišskou a Mezi Trhy v Opavě (Břečková 2017, 270, obr. 9:3). Odpadní jímka 563 obsahovala kromě pěti okenních terčíků, z nichž ale pouze jeden byl zdoben optickým dekorem žeber, také trojúhelníkovité výplně se zaštípanými hranami. Čtyři terčíky mají jednoduchý zatavený okraj, poslední má okraj zaštípaný. Jejich průměr je různý, od 110 do $140 \mathrm{~mm}$, pouze terčík s optickým dekorem má průměr $150 \mathrm{~mm}$. Další zlomky terčíku se žebry byly získány z hradu Cvilín u Krnova (Sedláčková 2004b, 374, obr. 3: 11).

Ani na Moravě nebyly terčíky s optickým dekorem příliš rozšîř́ené, doloženy jsou pouze v Brně na Dominikánské ulici 7 v kontextu 2. poloviny 15. století. Zde byla v odpadní jímce 546/00 nalezena okenní výplň vyštípaná z terčíku se žebry a část terčíku s dekorem čoček z lehce nazelenalého skla (Sedlácková 2007, fig. 45; Sedláčková ed. 2019b, 485, 489). V Čechách jsou doloženy pouze na Hradební ulici v Chrudimi. ${ }^{40}$ Terčíky s optickým dekorem byly nalezeny také v Budě (Gyürky 1986, tab. XLV; Sedláćková 2011a, 787). Vzhledem k dosavadní absenci nálezů tohoto typu okenního skla z jiných lokalit je pravděpodobné, že terčíky s optickým dekorem byly vyráběny ve sklárnách na severní Moravě či ve Slezsku (Sedláčková 2007, 219). Tuto teorii podporují výsledky analýz prvkového složení terčíku z Horního náměstí-Pekařské-Kolářské (tab. 2: A7), který je vyroben z draselno-vápenatého skla srovnatelného se skly vyráběnými ve 14 . až 1 . polovině 16 . století na našem území ${ }^{41}$ Okenní sklo s optickým dekorem ale v porovnání s celkovým objemem okenního skla v českých zemích ve středověku představovalo naprosto zanedbatelnou část.

Oblibu okenního skla zdobeného dekorem vzniklým předfouknutím do formy dokládají terčíky s motivem rozet, které byly nalezeny ve vraku lodi u Gnalić, jenž převážela sklo určené pro různé trhy ve Středomoří. Kvůli jejich malému počtu je možné, že byly vyrobeny pro specifické účely nebo přímo pro konkrétní stavbu (Lazar Willmott 2006, 72, fig. 93).

V pozdním středověku je doloženo zasklívání oken také na několika lokalitách v Ostravě. Zlomky terčíků s jednoduchým zataveným i přehnutým okrajem vyrobených z lehce nazelenalého a našedlého skla pocházejí z Masarykova náměstí, z vrstev datovaných do 2. poloviny 15 . a 1. třetiny 16 . století. Ze stejně datovaných vrstev byly získány zkorodované fragmenty okenního skla, mezi nimi i zlomky tabulky. ${ }^{42}$ Další terčíky z bezbarvého a našedlého skla a trojúhelníkovou výplň vyštípanou z terčíku obsahovala vrstva s. j. 355 ze 16 . století. ${ }^{43}$

Středověké okenní sklo, zejména terčíky, bylo nalezeno také na hradě Fürstenwalde u Vrbna pod Pradědem (Kouril - Prix - Wihoda 2000, 154) a Vikštejn. ${ }^{44}$ Další blíže nedatované fragmenty byly zachyceny pod hradbami 


\begin{tabular}{|c|c|c|c|c|}
\hline 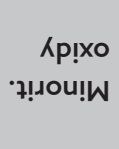 & 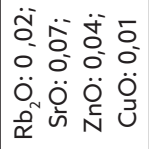 & & & \\
\hline${ }^{\varepsilon}$ OS & 옹 & & L & $\begin{array}{l}\text { กิ } \\
0 \\
0\end{array}$ \\
\hline כו & $m$ & $\stackrel{+}{0}$ & $m_{0}^{m}$ & $\begin{array}{c}\hat{m} \\
0\end{array}$ \\
\hline${ }^{2} \mathrm{O} ! \perp$ & $\tilde{O}$ & $\bar{\sigma}$ & & \\
\hline \multicolumn{5}{|l|}{ Oqd } \\
\hline \multicolumn{5}{|l|}{ org } \\
\hline Oגs & $\overline{0}$ & & & \\
\hline${ }^{s} O^{2} d$ & $\stackrel{\sigma}{\sigma}$ & $\stackrel{\infty}{0}$ & $\tilde{m}$ & $\underset{\sim}{\tilde{O}}$ \\
\hline $\mathrm{O}^{\circ} \mathrm{J}$ & L & $\bar{\sigma}$ & o & 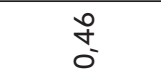 \\
\hline OuW & $\stackrel{+}{0}$ & $\hat{0}$ & $\stackrel{0}{0}$ & $\begin{array}{l}\infty \\
\stackrel{\infty}{0} \\
0\end{array}$ \\
\hline $\mathrm{O}^{6} \mathrm{~W}$ & $\hat{N}$ & $\stackrel{+}{m}$ & $\hat{m}$ & $\stackrel{\infty}{m}$ \\
\hline $\mathrm{O}^{\tau} \mathrm{eN}$ & $\bar{\sigma}$ & $\tilde{\sigma}$ & $\hat{\check{C}}$ & 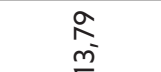 \\
\hline $\left.0^{2}\right\rangle$ & ò & $\begin{array}{l}\infty \\
\infty \\
\infty\end{array}$ & $\stackrel{\circ}{+}$ & $\bar{v}$ \\
\hline Oeכ & $\stackrel{m}{\stackrel{n}{=}}$ & $\begin{array}{l}m \\
0^{-} \\
-\end{array}$ & $\stackrel{+}{\circ}$ & $\begin{array}{l}\infty \\
\stackrel{0}{0} \\
\leftarrow\end{array}$ \\
\hline${ }^{\varepsilon} O^{\tau} \mid \forall$ & $\tilde{\sigma}$ & $\mathfrak{m}_{0}^{-}$ & $\stackrel{n}{r}$ & $\stackrel{\infty}{\circ}$ \\
\hline${ }^{2} \mathrm{O} S$ & นั้ & $\begin{array}{l}\infty \\
\infty \\
\infty \\
\omega^{-}\end{array}$ & นู้ & \begin{tabular}{l}
$m$ \\
\multirow{2}{*}{} \\
जo
\end{tabular} \\
\hline • ג & P) & 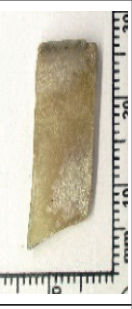 & P & (4) \\
\hline s!dod & 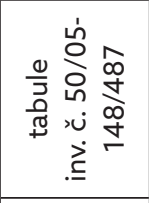 & 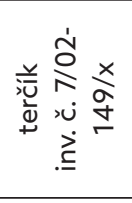 & 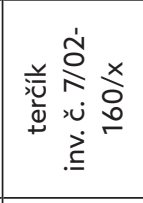 & 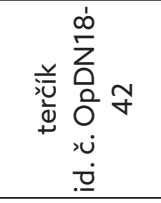 \\
\hline үәдоz^ & $\sum_{i x}^{0}$ & $\&$ & $\stackrel{\infty}{<}$ & 是 \\
\hline
\end{tabular}

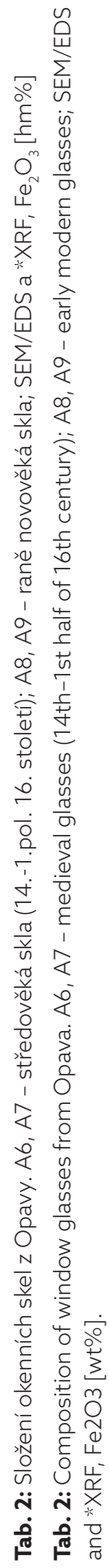




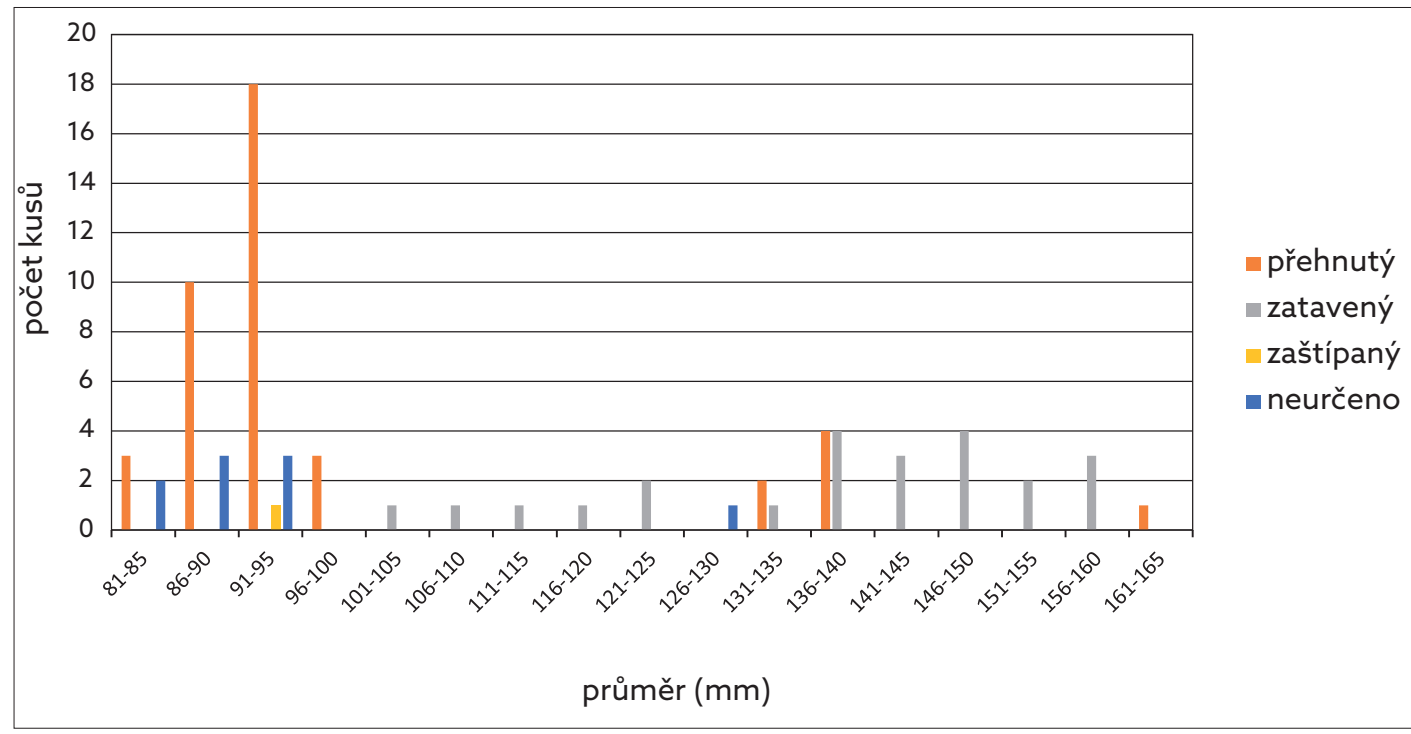

Graf 1: Průměr gotických a renesančních okenních terčíků z českého Slezska ve vztahu k typu okrajů. ${ }^{46}$

Graph 1: Diameter of Gothic and Renaissance crown glass discs from Czech Silesia in relation to rim type.

Slezsko-ostravského hradu. ${ }^{45}$ Početnější soubor okenního skla složený převážně z terčíků s jednoduchým zataveným okrajem (pouze jeden má okraj přehnutý) a trojúhelníkových výplní se zaštípanými hranami byl získán z hradu Cvilín u Krnova (Sedláčková 2004b, 374). Většina terčíků je ale silně zkorodovaná, jen výjimečně se dochovalo skelné jádro z bezbarvého až lehce našedlého skla. Vedle nezdobených exemplářů soubor obsahoval také dva zlomky terčíků s optickým dekorem, které již byly představeny výše.

Rozměry středověkých a raně novověkých okenních terčíků z archeologických výzkumů v českém Slezsku se pohybují od 80 do 165 mm, nejčastěji jsou ale doloženy terčíky o průměru 80-100 mm. Rozměry terčíků ani typy okrajů nejsou chronologicky citlivé, jistou vazbu lze ale pozorovat mezi těmito dvěma parametry. Většina exemplářů s přehnutými okraji má průměr v rozmezí $80-100 \mathrm{~mm}$, méně často pak v rozmezí 130-140 mm, zatímco terčíky se zataveným okrajem mají průměr 100-160 mm (viz graf 1).

\section{Sklenář na Drůbežím Trhu}

Zajímavý doklad městských řemesel přinesla odpadní jímka s. j. 505 na Drůbežím Trhu, která podle stabilního katastru náležela $\mathrm{k}$ domu č. 319 stojícím v severovýchodní části ulice Mezi Trhy. Jednalo se o trojvárečný dům, jenž sice nedisponoval plným rejstříkem práv, ale díky své exponované poloze mezi opavskými náměstími jistě patřil k prestižním nemovitostem (Kiecoň Zezula 2007, 6-7).

$\mathrm{Z}$ vrstev s. j. 148 a 150 bylo kromě devíti fragmentů terčíků s jednoduchým zataveným i přehnutým okrajem získáno nejméně 300 zlomků okenních tabulí z lehce nazelenalého nebo zkorodovaného skla a části olověných rámečků, kterými byly jednotlivé tabulky i terčíky spojovány. ${ }^{47}$ Výrazně převažují velmi drobné zlomky, pouze několik fragmentů svými rozměry překračuje $50 \mathrm{~mm}$. Zajímavá je převaha okrajových zlomků nad fragmenty středních částí tabulek. Téměř všechny okrajové zlomky mají navíc velmi podobný tvar: jsou úzké, 
s jednou ostrou obloukovitou hranou a druhou rovnou hranu tvoří zatavený okraj (tvar kruhové úseče, viz obr. 10:5). Další zlomky mají tvar kruhové úseče s obloukovitým výřezem na rovné hraně nebo srpečkovitý tvar (viz obr. 10:6). Shodný či alespoň velmi podobný tvar velké části úlomků naznačuje, že se nejedná o náhodou fragmentarizaci způsobenou při užívání okenního skla či v důsledku uložení v odpadní jímce.

Při bližším prozkoumání bylo zjištěno, že tyto drobné úzké zlomky ve tvaru kruhové úseče představují výrobní odpad, který vznikl při úpravě okrajů okenních tabulí vyráběných cylindrickou metodou. Také další zlomky svým tvarem odpovídají formě skleněných odštěpů po úpravě tabulového skla. Na řadě tabulek jsou navíc patrné i jiné výrobní stopy, například mnohočetné ryté linie, které měly zabránit poškození tabule skla tím, že by při odštipování kleštěmi došlo k ulomení většího kusu, než sklenář zamýšlel (obr. 10: 2, 4, 6). ${ }^{48} \mathrm{Na}$ hranách některých úštěpků lze pozorovat drobné defekty vzniklé při odlamování. Analýzy prvkového složení vybraného vzorku ukázaly, že tabulky jsou vyrobeny z draselno-vápenatého skla podobné kompozice jako regionální výrobky z tohoto období (tab. 2: A6).

Fragmenty okenních tabulí nalezené na Drůbežím Trhu korespondují se skleněným odpadem vzniklým při výrobním postupu, o jehož rekonstrukci se na základě nálezů z Bad Windsheim pokusila V. Kaufmann (2010, 43). V roce 2000 bylo nalezeno na tržišti v Bad Windsheim nalezeno obrovské množství výrobního odpadu z okenních tabulek. Ze dvou latrín bylo získáno ca $300 \mathrm{~kg}$ plochého skla, sklenářské nástroje a olověné zlomky. Vedle běžného nazelenalého nebo téměř bezbarvého skla soubor obsahoval i tabulky ze skla barevného a zdobené malbou. ${ }^{49}$ Okenní sklo se zřejmě dostalo do jímek najednou někdy po roce 1451, po ukončení provozu sklenářské dílny. O tom, že sklenář na lokalitě již dále nepůsobil, svědčí sklářské nástroje vyhozené spolu se skleněným odpadem (viz Kaufmann 2010).

Představený soubor okenního skla z Drůbežího Trhu je tak zřejmě pozůstatkem sklenářské dílny, která na lokalitě fungovala v 1 . polovině 15. století. Do této dílny bylo dováženo tabulové sklo pravděpodobně z některé z regionálních skláren. Tyto tabule pak místní sklenár dále zpracovával podle potřeby konkrétních zákazníků. Okraje okenních tabulí vyrobených cylindrickou metodou byly silnější než střední části, proto musely být odstraněny a hrany upraveny zaštípáním do požadovaných rozměrů. Sklenář si nejdříve na skleněnou tabuli s jednoduchými zatavenými okraji předrýsoval tvar výsledných tabulek, tabuli podle těchto linií rozlámal, a poté několikanásobnými rytými liniemi vyznačil okraje, které měly být odštípány. Pomocí nářadí pak postupně odlámal první linii větších úštěpků (zlomky s jednou rovnou zatavenou nebo ostrou hranou), poté vzniklou hranu důkladněji opracoval odštípáním menších kousků. ${ }^{50}$ Tento postup sklenář opakoval, dokud hrany nebyly dokonale opracovány (viz obr. 8).

Interpretace tohoto souboru ale přináší více otázek než odpovědí. Působil sklenář na Drůbežím Trhu dlouhodobě nebo se jednalo pouze o jednorázovou akci? Na tuto otázku bohužel archeologie nedokáže spolehlivě odpovědět. Jelikož neznáme výsledné rozměry okenních tabulí, ani zda byly odštípány všechny hrany, nelze ani odhadnout, z jakého počtu oken tento výrobní odpad pochází.

Již dříve představená tabulka zdobená malbou (viz obr. 6) a nejméně osm dalších fragmentů vitrají nás navíc vede $\mathrm{k}$ otázce, zda sklenář vedle běžného tabulového skla $\mathrm{z}$ nepříliš kvalitního nazelenalého skla vyráběl i barevná vitrajová okna. Pokud ano, kdo byl objednatelem takto nákladného výrobku? Je možné, že vitraje byly určeny pro některý z opavských 


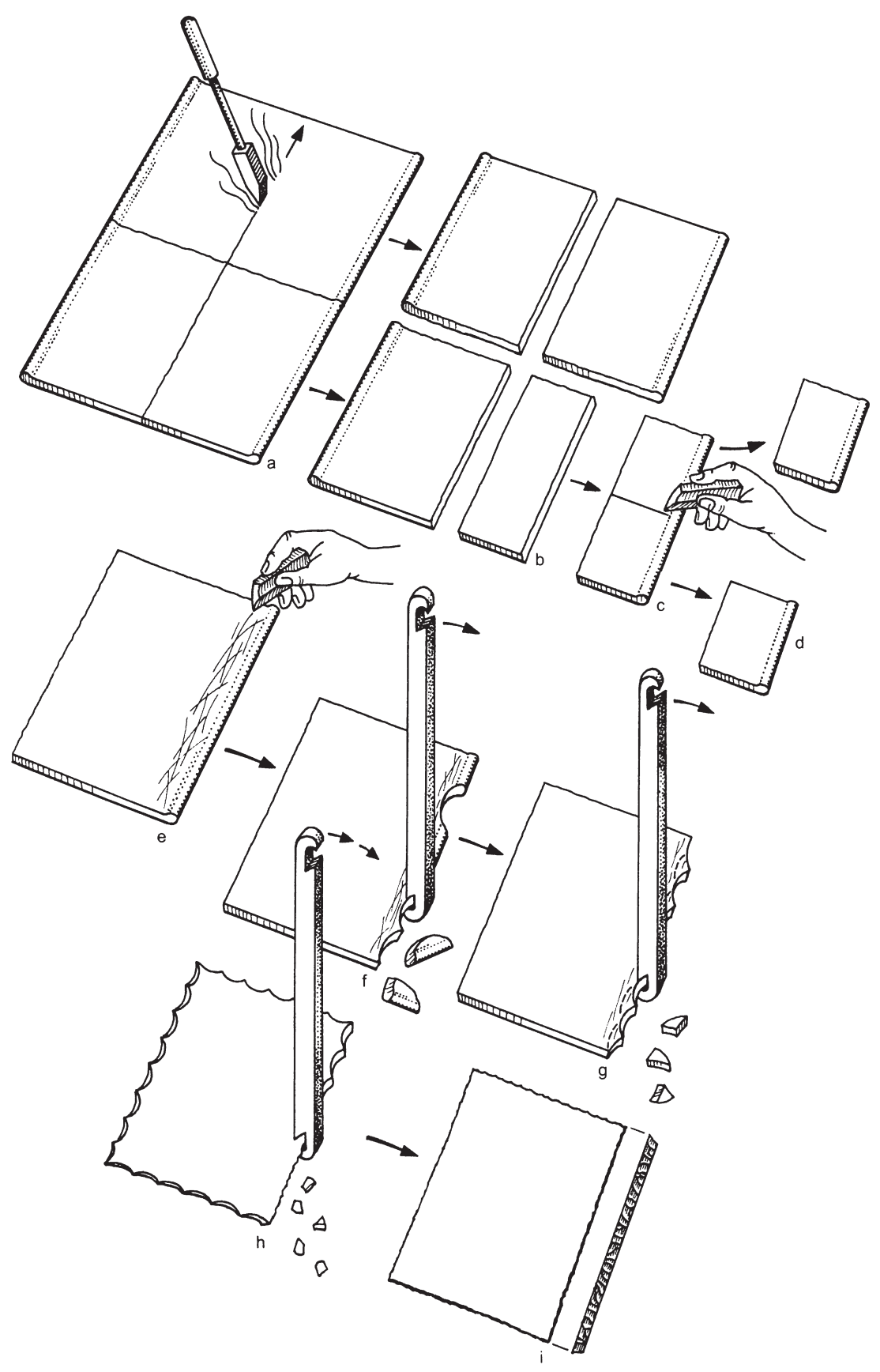

Obr. 9: Rekonstrukce postupu výroby okenních tabulek (podle Kaufmann 2010, abb. 54).

Fig. 9: Reconstruction of the production sequence of windowpanes (after Kaufmann 2010, Abb. 54). 

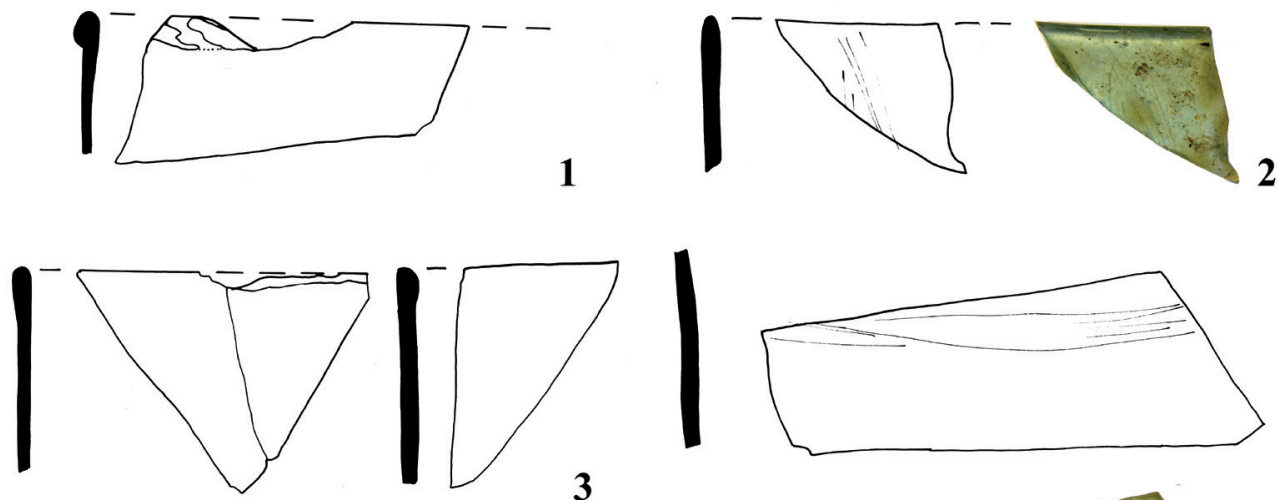

3
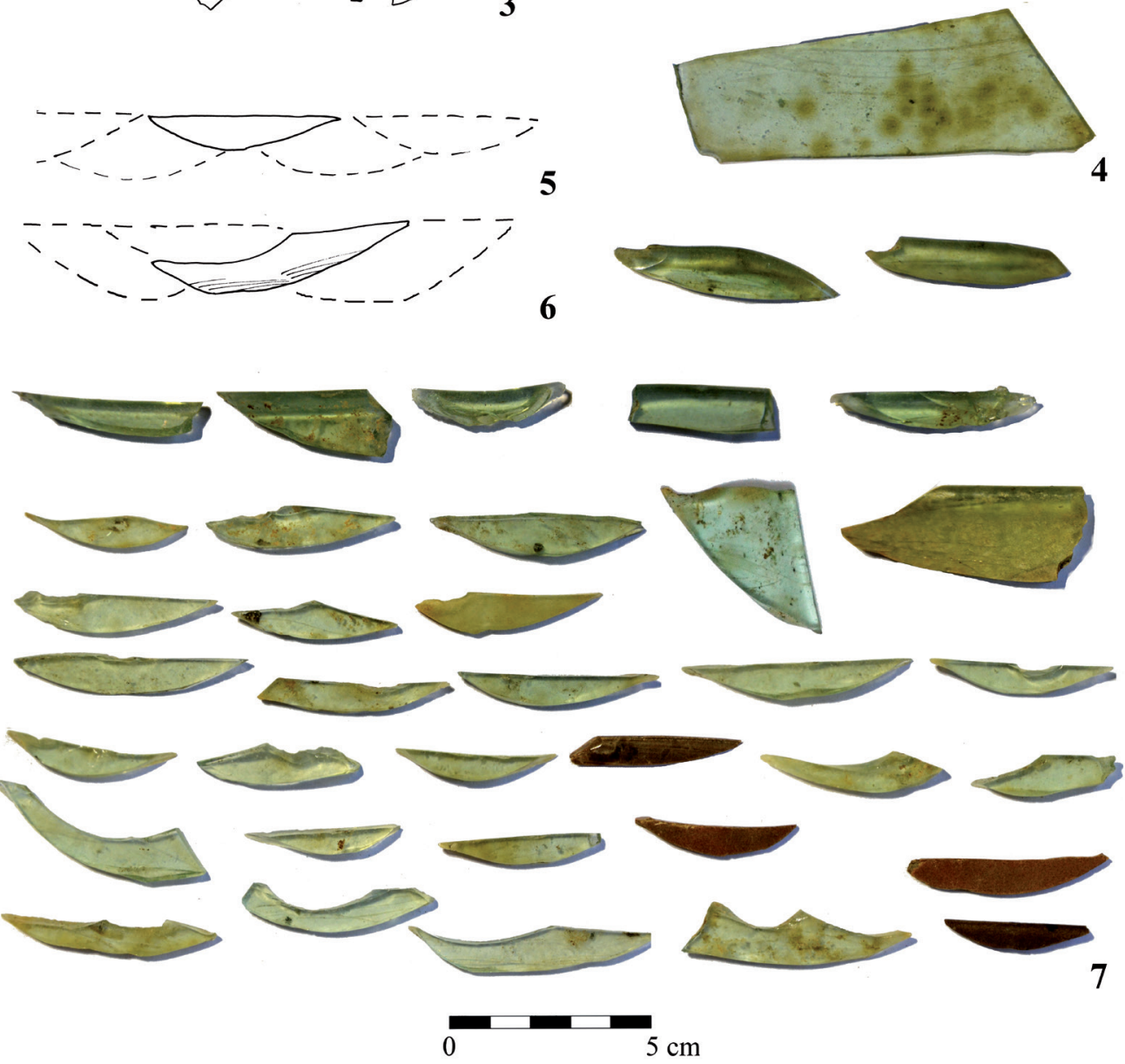

Obr. 10: Výrobní odpad z okenních tabulek. Opava, Drůbeží Trh, objekt 505. NPÚ, ÚOP v Ostravě. Kresba a foto: K. Vad'urová.

Fig. 10: Production waste from windowpanes. Opava, Drůbeží Trh, Feature 505. National Heritage Institute, regional branch Ostrava. Drawing and photo: K. Vad'urová. 
chrámů, vyloučit ale nelze ani domy lépe situovaných opavských měštanů či šlechty. Zde se ale již zcela pohybujeme na poli spekulací.

\section{Renesanční okenní sklo: polovina 16. století - 1. polovina 17. století}

Také v raném novověku byla významná část produkce českých, moravských i slezských skláren zaměřena na uspokojení poptávky po okenním skle pro světské i církevní stavby. V období renesance již ustoupilo sklo vitrajové zdobené malbou a nahradilo ho nezdobené okenní sklo ve formě obdélníkových, kosodélníkových či šestibokých tabulek a okenních terčíků. O různých kompozicích oken si můžeme udělat představu nejen na základě materiálu z archeologických výzkumů, ale i z dobových vyobrazení, rytin a maleb zachycujících interiéry renesančních domů a paláců. ${ }^{51}$ Obrovskou spotřebu okenních terčů v 16. a 17. století ilustrují historické písemné zprávy o dovozu okenního skla. Terčíky byly baleny a počítány po truhlách a do jedné truhly se podle velikosti vlezlo asi 1500-2500 kusů. Podle J. Lněničkové (2004, 15) sestávala průměrná objednávka asi z tř́i až pěti truhel. Pouze terčíky z kvalitnějšího skla byly pravděpodobně počítány na kusy.

V českých zemích je okenní sklo běžnou součástí renesančních archeologických souborů z městského prostředí, šlechtických sídel i církevních staveb. Jinak tomu není ani v Čechách a na Moravě (Curková - Černá 2007, 83, 88; Podliska 2003, 89; Sedláčková 1997, 65-66). Šírí se dokonce i v prostředí nižších měštanských vrstev.

Okenní i duté sklo renesančního tvarosloví bylo nalezeno v odpadní jímce 512 ve vnitrobloku mezi Horním náměstím-Pekařskou-Kolářskou, která byla na základě keramiky datována od přelomu 15./16. století až do průběhu 16. století. ${ }^{52} \mathrm{Z}$ jímky byly vyzvednuty zlomky nejméně 11 okenních terčíků převážně s přehnutým okrajem z našedlého, nazelenalého, zelenomodrého a bezbarvého skla (obr. 11: 2-4). Nejméně dva terčíky měly jednoduché zatavené okraje a jediný terčík okraj zaštípaný. Průměr těchto terčíků se pohyboval v rozmezí 90-95 mm, pouze terčíky se zataveným okrajem dosahovaly většího průměru (105 a 115 mm). Analýzy prvkového složení jednoho terčíku z našedlého skla ukázaly, že je vyroben ze sodno-draselno-vápenatého skla blízkého benátským sklům typu Common glass (tab. 2: A8). Je ale pravděpodobné, že i další terčíky z našedlého skla jsou vyrobeny z tohoto typu skla.

Sodno-draselno-vápenaté sklo typu Vitrum blanchum bylo identifikováno u terčíku s přehnutým okrajem z Dolního náměstí 18 (tab. 2: A9). ${ }^{53} \mathrm{~V}$ odpadní jímce z přelomu 16. a 17. století bylo nalezeno nejméně osm okenních terčíků s přehnutým okrajem z nazelenalého až našedlého skla a jeden terčík ze skla zelenomodrého (obr. 11: 5-7). Jejich průměr se pohyboval v rozmezí $90-100 \mathrm{~mm} \cdot{ }^{54}$ Analyzován byl pouze jeden terčík, ale podobné složení skla lze předpokládat i u dalších exemplářů $\mathrm{z}$ tohoto objektu.

$\mathrm{V}$ renesanci byl do sklářského kmene přidáván $\mathrm{NaCl}$ kvůli zlepšení vlastností skla. Výrobky slezských a moravských renesančních skláren ale obsahují maximálně $4 \mathrm{hm} \% \mathrm{Na}_{2} \mathrm{O}$ (Sedláčková - Rohanová et al. 2016, 237, diagram 7), zatímco v analyzovaných opavských terčících byl obsah $\mathrm{Na}_{2} \mathrm{O}$ 12,7 a 13,8 hm\%. Tyto okenní terčíky ze skla s vyšším obsahem $\mathrm{Na}_{2} \mathrm{O}$ představují na našem území importy. Kromě Opavy jsou terčíky ze sodno-draselno-vápenatého skla doloženy na několika parcelách v Brně. Na Mečové 2 byly nalezeny terčíky ze skla typu „mixed-alkali“, které bylo vyráběno například ve sklárnách v Hall a v Tyrolsku. Okenní terčík z Panské 6 má podobné složení jako benátská skla typu Common glass (Sedlácková - Rohanová et al. 2016, 246, tab. 6: A050, A052, tab. 11: A122). ${ }^{55}$ 
Na základě nálezů z Horního náměstí bylo možné rekonstruovat původní vzhled okna složeného z kruhových terčíků (Štěrbová - Pavelčík 1997, 159, obr. 6). Na místě, kde v renesanci stál dům Macáků z Ottenburku, bylo nalezeno 15 celých terčíků a 587 zlomků okenního skla. Terčíky mají průměr $80,81,86,88,90,92,93,94$ a $127 \mathrm{~mm}$ a jsou vyrobeny většinou ze skla bezbarvého, méně ze skla nazelenalého. Při okraji okna byly osázeny poloviny terčíků, zbytek okna sestával z celých terčíků a mezery mezi nimi byly vyplněny trojúhelníkovými výplněmi. Těch zde bylo nalezeno celkem 72 kusů. Na povrchu terčíků byly údajně stopy modré a žluté barvy. Výplň jímky obsahovala také několik úlomků a slitků olova, které pocházely z olověných profilů. Větší část olova byla zřejmě znovu použita.

Okenní terčíky s fragmenty olověných profilů byly získány také z výzkumu dominikánského kláštera v roce 1968. V moravské kapli kostela sv. Václava byly nalezeny terče, které jsou na rozdíl od všech předchozích exemplářủ vyrobeny talírovou metodou a nenesou tak stopy po přílepníku. ${ }^{56}$ Spolu s terčíky zde byla nalezena šestiboká tabulka se zaštípanými hranami z lehce nazelenalého skla. Zkorodované zlomky starších okenních terčík so přehnutými okraji a trojúhelníkových výplní byly v roce 1972 a 1975 získány ze sond v dominikánské kapli. Kvůli absenci terénní dokumentace ale nálezy nelze datovat. Šestiboké tabulky byly však použíány v českých zemích až od raného novověku.

Další drobná šestiboká tabulka $\mathrm{z}$ tenkostěnného bezbarvého skla a odpad z výroby těchto tabulek byl nalezen v Krnově na ulici Školní a Požárníků. Soubor skla z 16. až 1. poloviny 17. století obsahoval také několik terčíků s přehnutými okraji a trojúhelníkových výplní vyštípaných z okenních terčíků (Sedlácková 2015, 320-321).

Okenní sklo bylo zachyceno i na Masarykově náměstí v Ostravě ve vrstvách 2. poloviny 16. až počátku 17. století. ${ }^{57}$ Vedle tabulového skla zde byly zastoupeny terčíky s přehnutým okrajem z bezbarvého a lehce nazelenalého skla. Jeden z nich je rozlomen a hrana je zaštípaná, pravděpodobně se tak jedná o terčík, který byl osazen po obvodu okna.

Kromě Opavy, Ostravy a Krnova je raně novověké (renesanční) okenní sklo doloženo i v prostředí šlechtických sídel. Celý okenní terčík s přehnutým okrajem z nazelenalého skla o průměru $97 \mathrm{~mm}$ byl získán z hradu Sovince (obr. 11: 1). ${ }^{58}$ Nelze ale vyloučit, že tento terčík pochází ještě z některého ze středověkých oken hradu. Fragmenty dalších terčíků s přehnutým okrajem z nazelenalého skla a trojúhelníková výplň dokládají zasklení oken na hradě Starý Jičín. ${ }^{59}$ Průměr dvou terčíků je ca $90 \mathrm{~mm}$. Na základě optického posouzení skla a charakteru koroze je pravděpodobné, že se jedná o raně novověké výrobky. Bohatší soubor skla renesančního tvarosloví byl nalezen na zámku v Janovicích (Karel 2017, 95). Okenní sklo je zde reprezentováno zlomky terčíků z nazelenalého skla, trojúhelníkových výplní a tabulkami vyrobenými válcovou metodou.

O tom, že okenní sklo tvořilo běžnou součást produkce českých a moravských skláren svědčí nálezy ze sklářských hutí. Například v renesanční huti v Broumech byly nalezeny terčíky vyráběné korunovou i talířovou metodou (Žegklitz 2011, 198-201, obr. 29). ${ }^{60}$ Výroba okenních terčíků a tabulek z draselno-vápenatého skla je doložena i ve sklárnách na severní Moravě a ve Slezsku, např́íklad ve Sklené u Pustých Žibřidovic a Nové Senince na Šumpersku (Sedlácková - Rohanová et al. 2016, tab. 32: 506-508, tab. 34: A7/A525).

$\mathrm{Na}$ základě zastoupení okenních skel na všech lokalitách s novověkým sklem je pravděpodobné, že v 16. a 17. století již měly téměř všechny opavské domy v centru města zasklená okna. V soupise opavských cechů z roku 1608 je ale uveden pouze jediný sklenář, a to v bratrstvu 

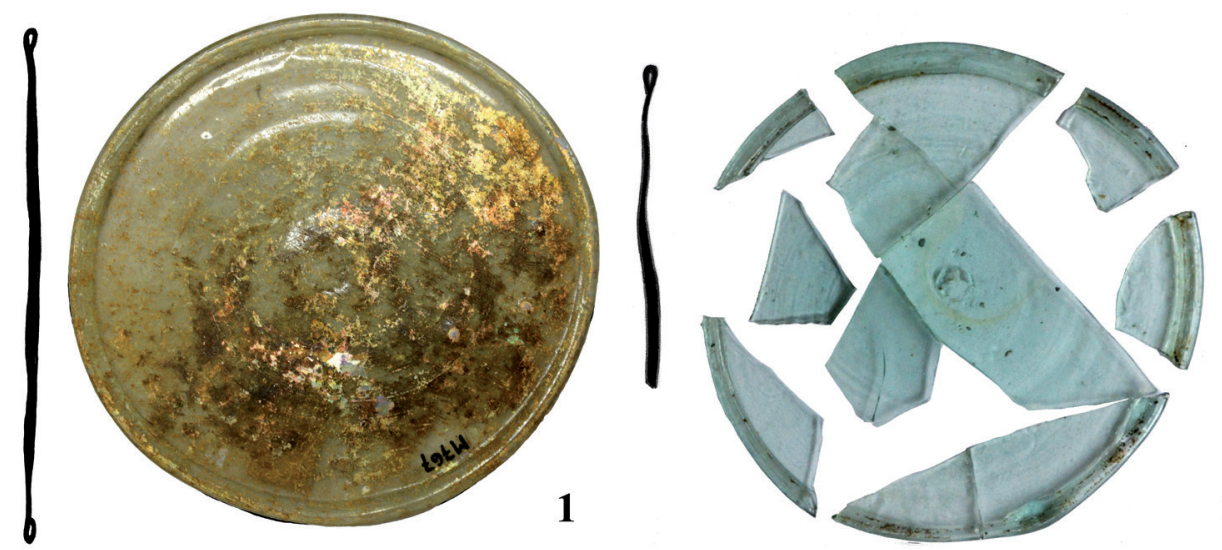

2
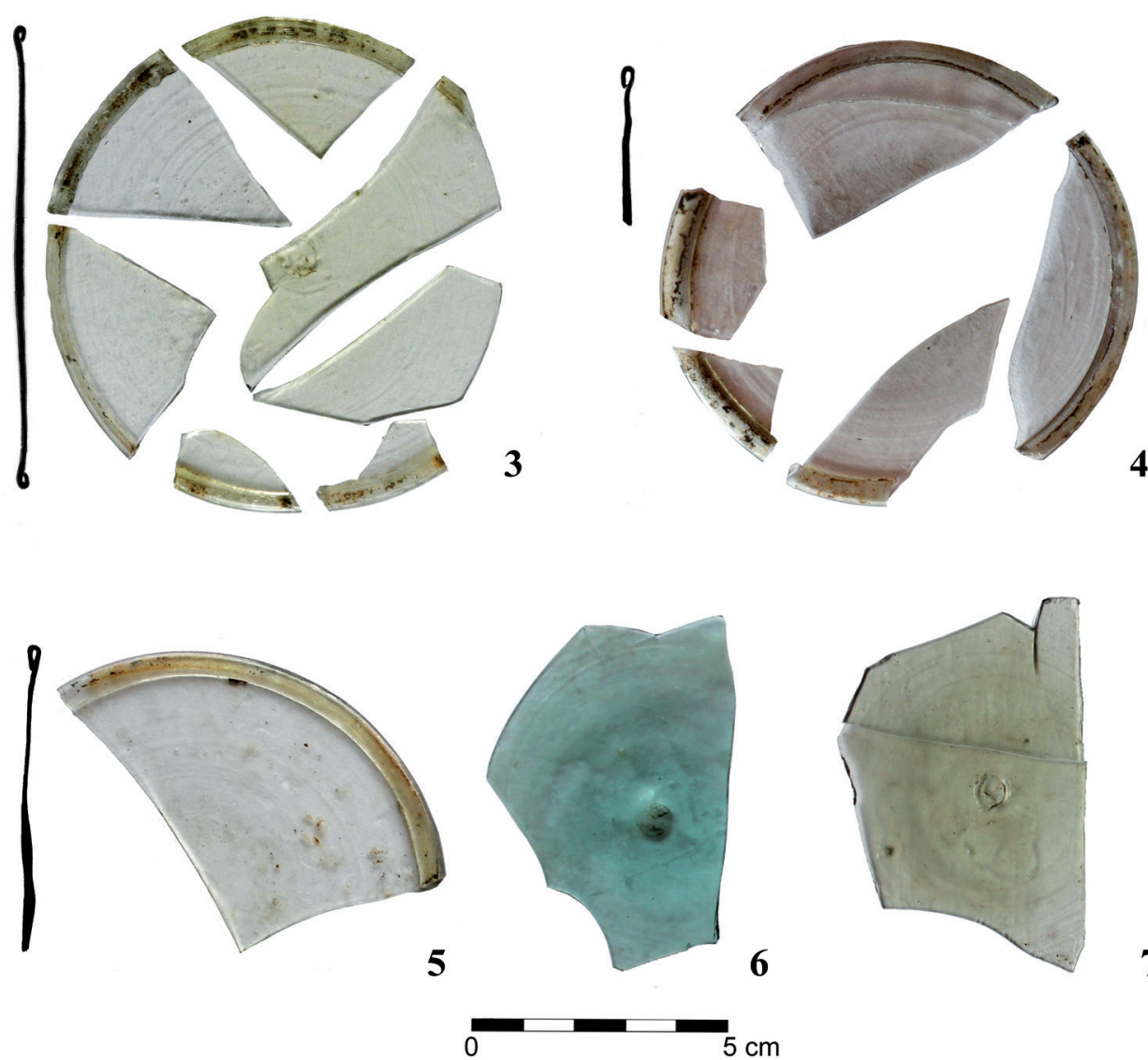

Obr. 11: Okenní terčíky z Opavy a ze Sovince. 1 - Sovinec; 2-4 - Opava - vnitroblok Horní náměstí- Pekařská-Kolářská; 5-7 - Opava - Dolní náměstí 18. SZM (1) a NPÚ, ÚOP v Ostravě (2-7). Foto: K. Vad'urová.

Fig. 11: Crown glass discs from Opava and Sovinec. 1 - Sovinec; 2-4 - Opava - inside the block of houses Horní náměstí - Pekařská - Kolářská; 5-7 - Opava - Dolní náměstí square 18. Silesian Museum (1) and National Heritage Institute, regional branch Ostrava (2-7). Photo: K. Vad'urová. 
u cechu zámečníků (Matějek 1967, 62) ${ }^{61}$ Do jaké míry tento záznam odráží skutečný stav, není jisté. Pokud ale budeme věřit písemným zprávám, je pravděpodobné, že do Opavy dováželi sklo i sklenáři z jiných měst.

\section{Závěr}

Jaký podíl tvořilo okenní sklo v celkovém objemu středověkých a raně novověkých sklářských produktů nelze přesně stanovit. Obecně je ale přijímána myšlenka, že rostoucí poptávka po okenním skle ve 13. a 14. století byla významným impulsem pro zakládání skláren. Nejdříve se jednalo především o dodávky skla pro církevní stavby a šlechtická sídla, později stále častěji i pro měštanské domy. Poptávka v průběhu středověku a raného novověku stále vzrůstala spolu se zvyšujícími se nároky na bydlení. $\mathrm{V}$ pozdně středověkém či raně novověkém archeologickém materiálu je již okenní sklo běžnou součástí téměř všech souborů.

Vzhledem k nízkému počtu analyzovaných vzorků nelze ani odhadnout, jakou měrou se na zásobování okenním sklem v českém Slezsku podílely regionální sklárny a jaký podíl tvořilo sklo dovážené $z$ větších vzdáleností. Nicméně dovoz okenního skla je doložen archeologickými prameny již od 13. století, kdy se v souborech z Opavy a Bohušova objevuje okenní sklo z německých skláren a z hutí v jižní Evropě. ${ }^{62}$ Ostatně ještě v 15. století bylo podle písemných pramenů do Slezska dováženo průhledné okenní i duté sklo z Benátek (Czihak 1891, 4). Paralelně se ale rozvíjela i lokální výroba. Lokální provenience je zřejmě většina okenních terčíků i tabulek z draselno-vápenatého skla z 15. století, jak dokládají nálezy z Drůbežího Trhu a Horního náměstí-Pekařské-Kolářské. Kromě místního trhu bylo ale regionální sklo určeno také na export, což dokumentuje např́klad smlouva z roku 1376, kde se jistý sklenář Nico- las Queysser ze Zábřehu na Moravě nebo Sklenařic u Vysokého nad Jizerou zavázal dodat 32 set $^{63}$ skla Hanuši z Głogówa (Lněničková 2004, 14). Sklo z místních skláren bylo použito také k zasklení oken kláštera ve Vratislavi (Czihak 1891, 4).

V období renesance se vedle terčíků z draselno-vápenatého skla objevují importované terčíky ze skla sodno-draselno-vápenatého, jaké známe například z Opavy - Dolního náměstí 18 a Horního náměstí-Pekařské-Kolářské. Metoda výroby ale zůstávala stále stejná. Pouze několika exempláři z dominikánského kláštera jsou v českém Slezsku doloženy terčíky vyráběné talírovou metodou používanou od 16. století.

Zaměříme-li se na sociální prostředí, ve kterém se nacházejí stř̌edověká okenní skla, zjistíme, že nejstarší nálezy (ze 13. století) se koncentrují kolem církevních staveb, ale objevují se i v měštanském prostředí. V př́ípadě Opavy je to především na několika prestižních parcelách v těsné blízkosti Horního a Dolního náměstí, kde stály ve středověku domy majetnějších měštanů s plnými právy. Záhy se okenní sklo objevuje také ve šlechtickém prostředí. Od poloviny 14. a spíše v 15. století se pak šíŕí i mezi střední měštanské vrstvy a řemeslníky, jak dokládají nálezy dále od centra města. V renesanci je okenní sklo již rozšířeno mezi široké vrstvy obyvatel. Běžně nalézáme okenní sklo kromě Opavy i v menších městech, jako byla Ostrava, Krnov a Bruntál. Větší soubory ale pocházejí pouze z několika lokalit, což by nasvědčovalo recyklaci, kdy byla rozbitá skla sbírána a svážena zpět do skláren, kde byla přidávána do sklářského kmene.

Celý proces od výroby okenního skla, přes dopravu až po jeho úspěšné osazení do okenních otvorů domů či kostelů představuje logisticky i ekonomicky náročný proces. Cestu okenního skla lze rozdělit do několika etap. První je jeho samotná výroba, která probíhala ve sklářských hutích. Ve Slezsku byly sklárny z důvodu snadné dostupnosti surovin situovány 
především v dnešním česko-polském pohraničí $\mathrm{v}$ zalesněných oblastech. Ze skláren putovaly okenní terče a tabule ke sklenářům, kteří z nich vyštípali požadované tvary a sesadili je pomocí olověných pásků. Během tohoto procesu mohlo být okenní sklo také dozdobeno malbou a poté bylo dopraveno na místo určení. V př́ípadě církevních staveb lze z praktických důvodů kvůli velké spotřebě okenního skla uvažovat i jeho finální zpracování až na místě stavby (Sedláčková 2011b, 299-300). ${ }^{64}$ Vzácné doklady o působení sklenáře $\mathrm{v} 1$. polovině 15 . století byly nalezeny na Drůbežím Trhu v Opavě.

V souvislosti se zasklíváním oken je nutné zmínit velkou spotřebu olova na výrobu olověných rámečků. Zejména $\mathrm{v}$ případě větších církevních staveb bylo toto množství nezanedbatelné. Jak již bylo zmíněno dříve, zlomky olověných okenních profilů byly nalezeny v odpadních jímkách v Opavě na Drůbežím Trhu, Kolářské ulici, na Horním náměstí a v kostele sv. Václava u dominikánského kláštera. Zají- mavým nálezem jsou olověné slitky, fragmenty červených opakních „skelných strusek“ a zlomků olova z výzkumu dominikánského kláštera, které dokládají zpracování olova na lokalitě ve 13. století. Zda je možné interpretovat tyto nálezy v souvislosti se stavbou kláštera dominikánů, která zřejmě vyžadovala velké množství olova pro střechu a okna, nebo zda se jedná o doklad starší výroby nelze $\mathrm{z}$ důvodu absence terénní dokumentace určit.

Cílem toho příspěvku nebylo podat dokonalý výčet všech nálezů okenního skla v českém Slezsku, což vzhledem k četnosti archeologických výzkumů ani není reálné, nýbrž nastínit potenciál a výpovědní možnosti této skupiny hmotných pramenů. Okenní sklo poskytuje informace nejen k typologii užívaných výrobků, ale také o úrovni řemesel a používaných výrobních technologiích, obchodních kontaktech a sociálním postavení jeho uživatelů. Přesto patří okenní sklo stále mezi spíše opomíjené archeologické prameny.

1) Většina materiálu pochází z výzkumů vedených Národním památkovým ústavem, ÚOP v Ostravě (dále jen NPÚ, ÚOP v Ostravě), a z výzkumů Slezského zemského muzea (dále jen SZM).

2) Historií okenního skla v Čechách a jeho výrobou se zabývala např́íklad E. Černá (2004) a J. Lněničková (2004).

3) Jednotlivé sklářské hutě mohly používat různé varianty této metody (viz Kaufmann 2010, abb. 5).

4) V literatuře jsou často zaměňovány pojmy vitráž a vitraj. Vitráž (z francouzského le vitrage, z původního latinského vitrum, což znamená sklo) je obecný název pro skleněné okenní uzávěry, tedy pro nezdobené i dekorativní prvky z plochého barevného i nebarveného skla. Vitraj (z francouzského le vitrail) označuje dekorativní okno sestavené z barvených skleněných plošek, z malovaného skla nebo ze skla reliéfně zdobeného. Toto označení bývá užíváno pro středověkou historickou malbu na skle, která je vnímána jako samostatný umělecký obor (Losos 2006, 8). Výroba vitrají vyžadovala kromě znalosti výroby plochého skla i znalost technik barvení skla a malby. Vitraj je tedy názvem pro uměleckou vitráž.

5) Terčíky vyrobené oběma těmito metodami mají uprostřed stopu po př́lepníku a stopy po roztáčení (např. protáhlé bubliny po směru rotace terčíku).

6) Např́íklad v Praze působilo na přelomu 14. a 15. století zhruba 20 sklenářů, v Brně 16 (Losos 2006, 26). K velkému nárustu počtu sklenářu došlo v 1. čtvrtině 16. století (Lněnickovaá 2004, 15).

7) Nürnberger Hausbücher je pětidílná sbírka portrétů obyvatel dvou norimberských chudinských domů.

8) Středověkých a raně novověkých vyobrazení sklenářů a malířu skla je samozřejmě více, ale podat vyčerpávající seznam všech ikonografických pramenů není v možnostech tohoto příspěvku.

9) Městští sklenáři se př́ímo nepodíleli na výrobě skla. Jejich pracovní náplň sestávala z řady různorodých aktivit od nákupu skla v hutích až po distribuci koncovým uživatelům. Jednou z hlavních činností bylo zpracování okenního skla - vyštípání požadovaných tvarů, malba a její výpal ve speciální peci, sestavení vitráží a osazení do okenních otvorů. Vedle okenního skla se ale mohli věnovat i výrobě korálků z polotovarů a výzdobě dutého skla. 
10) Na základě písemných pramenů víme, že skláři odváděli vrchnosti nejenom finanční dávky, ale také hotové skleněné výrobky (viz výše).

11) Podrobněji ke středověkých a raně novověkým sklárnám na severní Moravě a ve Slezsku viz Šrámková 2012.

12) O této variantě lze uvažovat jen pokud byla hut̉ tak blízko, že se sklář stihl vrátit během jednoho dne a mohl pokračovat ve výrobě.

13) Tento mechanismus distribuce dokládá záznam krakovské městské rady z roku 1561, v němž jsou jmenováni kupci z Krakova, kteří mohou ze sklářských hutí nakupovat sklo. Dalším a zřejmě častým zpưsobem dopravy skla do měst bylo prostřednictvím formanů, kteří přepravovali sklo na zakázku na náklady sklárny nebo kupujícího (Wyrobisz 1968, 174).

14) České sklo bylo dováženo také do Gdaňsku, který byl zásobován i množstvím dalšího zahraničního skla, především francouzského, anglického, německého a benátského. Odtud distribuovali kupci sklo dále na dvory polské šlechty a do Pobaltí (Wyrobisz 1968, 189).

15) První písemná zpráva o této sklárně pochází z roku 1577 (Štěpán - Štěrbová 2001, 235).

16) Srovnej s Černá 2004, 23.

17) Konturová čerň (švarclot) nemusela být vždy černá. Její výsledná barva závisela na teplotě, kterou byla na skle vypálena, a na způsobu přípravy. Oxid olovnatý byl do směsi přidáván za účelem snížení teploty tavby. Na vypálení barvy tak postačovala teplota ca $600{ }^{\circ} \mathrm{C}$ (Sedláčková 2011b, 300).

18) V roce 1348 bylo takové bratrstvo založeno při kostele sv. Panny Marie na Louži v Praze. Prvním mistrem tohoto bratrstva se stal Theodorik, dvorní malír Karla IV.

19) Oba soubory byly zpracovány H. Sedláčkovou $(2009 ; 2011 b)$.

20) Kromě okenního skla zde byly nalezeny pouze zlomky dvou skleněných nádob.

21) Od konce 12. století je výroba olovnatého skla doložena ve sklárnách v Hils v Dolním Sasku (Wedepohl - Krueger - Hartmann 1995, 65-82).

22) Inv. č. 27/03-153/144, 50/05-462/2, 50/05-371/13, 50/05-208/3, NPÚ, ÚOP v Ostravě.

23) Inv. č. 6/02-354/105, NPÚ, ÚOP v Ostravě. Zlomek byl nalezen ve vrstvě s. j. 354 spolu s fragmenty zkorodovaného skla a láhve s vnitřním prstencem $\mathrm{z}$ hnědého skla.

24) Negativní malba pomocí šablony.

25) Stavbě kláštera podle V. Štěpána předcházela starší stavba, jejíž zbytky jsou včleněny do kostela sv. Václava (Štěpán 2014, 20-21).

26) Podrobně k dějinám kláštera viz Štěpán 2014.

27) Přír. č. $87 / 1$, SZM.

28) Vysoký obsah $\mathrm{K}_{2} \mathrm{O}$ lze vysvětlit přidáním kapradí nebo potaše (výluh z popela, $\mathrm{K}_{2} \mathrm{CO}_{3}$ ) do sklářského kmene, ale pro jeho užití v tak časném období nejsou doklady.

29) Ze skla této kompozice byly v Opavě doloženy také nádoby i skleněné kroužky (Vad’urová 2019).

30) Vitrum silvestre sive montanum. Okenní benátské sklo bylo označováno například jako vitra veneciana (viz Czihak 1891, 4).

31) Byly vyštípány z okenních terčíků nebo tabulí.

32) Často se různé stupně koroze projevují i na stejných fragmentech, což je způsobeno rozdílnými lokálními podmínkami v odpadní jímce.

$33)$ Inv. č. 1/01-193/71, NPÚ, ÚOP v Ostravě.

34) Vzhledem k dlouhé životnosti okenního skla je nelze blíže datovat.

$35)$ Inv. č. 3/04-175/64, 3/04-178/43, 2/98-1122/58, NPÚ, ÚOP v Ostravě.

36) Z jednoho terčíku o průměru $90 \mathrm{~mm}$ z lehce našedlého skla se zachovalo větší torzo.

37) Podle historických písemných pramenů se ve středověku na obou náměstích nacházely plnoprávné domy bohatých měštanů a šlechty (Bartková 2009, 18-19).

38) Pouze u dvou terčíků mohl být průměr větší, až $160 \mathrm{~mm}$.

39) Vzniklé hrany byly pečlivě zaštípané. 
40) Dosud nepublikovaný exemplář pochází z odpadní jímky 973, ze spodní vrstvy její výplně (s. j. 145; Kozáková Frolik 2011, obr. 4). Uloženo v Regionálním muzeu v Chrudimi.

41) Za provedení a vyhodnocení výsledků těchto i dalších analýz uvedených v příspěvku děkuji doc. Dr. Ing. Daně Rohanové z VŠCHT.

42) Inv. č. 35/06-181/84, 35/06-219/160, 35/06-339/125, 35/06-339/233, 35/06-356/251, 35/06-365/141, NPÚ, ÚOP v Ostravě.

43) Inv. č. 35/06-355/131, NPÚ, ÚOP v Ostravě.

44) Inv. č. M 766 a př́r. č. $68 / 49$, SZM.

45) Inv. č. AE 0/101, Ostravské muzeum.

46) Do skupiny „neurčeno“ jsou řazeny okenní terčíky z Horního náměstí parc. 178. V příspěvku od J. Štěrbové a J J. Pavelčíka (1997) není uvedeno, jaký typ okrajů měly okenní terčíky.

47) Inv. č. 50/05-148/478, 50/05-150/89, NPÚ, ÚOP v Ostravě.

48) Srovnej s Kaufmann 2010, 113, 118, 120, abb. 46.

49) Existenci sklenářské dílny na této lokalitě potvrdily i záznamy v městských knihách z let 1393-1451 (Kaufmann 2010, 245-261).

50) Tyto odštěpky mají všechny hrany ostré.

51) Např́iklad ve spise J. Ammana jsou okna zobrazena na několika rytinách (Amman - Sachs 1568). Online zdroj: https://de.wikipedia.org/wiki/Jost_Amman\#/media/File:Formschneider.jpg

52) Akce 7/02, neinventováno, NPÚ, ÚOP v Ostravě.

53) Srovnáváno s hodnotami podle M. Verità (2009).

54) Neinventováno, NPÚ, ÚOP v Ostravě.

55) Obsah $\mathrm{Na}_{2} \mathrm{O}$ je $14,8 \mathrm{hm} \%$.

56) Př́r. č. 68/24, SZM.

57) Inv. č. 35/06-109/181, 35/06-150/701, 35/06-150/711, NPÚ, ÚOP v Ostravě.

58) Inv. č. M 767, SZM.

59) Přír. č. 54/443, SZM.

60) V požárové vrstvě z roku 1600 zde byly nalezeny terčíky naskládané do sloupců a uložené v dřevěné truhle nebo na polici (̌̌egklitz 2011, 176, obr. 9).

61) V tomto bratrstvu je uveden i jeden lazebník a pištec. Do cechu zámečníků patřili také 3 mečíři, pilníkář, prsteník, mědirytec, puškař a hodinář

62) Původ v severoitalských sklárnách lze předpokládat u kvalitního bezbarvého tabulového skla z Opavy (Sedláčková 2011a, 769, 775).

63) Jedná se o tzv. hutní sta. Odhadovaný počet kusů je 800 až 2000 . Vzhledem k tak vysokému počtu je pravděpodobné, že se jednalo o sklo okenní (Lněničková 2004, 14)

64) Například pro okna kostela v Bohušově odhaduje H. Sedláčková spotřebu nejméně $600 \mathrm{~kg}$ skla. 


\section{Bibliografie}

Amman J. - Sachs, H. 1568: Eygentliche Beschreibung aller Stände auff Erden, hoher und nidriger, geistlicher und weltlicher, aller Künsten, Handwercken und Händeln. Frankfurt am Main.

Bartková, M. 2009: Historické názvy ulic a náměstí v Opavě - Historical names of streets and places in Opava. Bakalářská práce. Univerzita Palackého v Olomouci. Filozofická fakulta. Katedra bohemistiky. Vedoucí práce: $\mathrm{O}$. Bláha.

Bláha, J. 2000: Nálezy vitrají a dutého skla z období raného středověku na lokalitě Olomouc - Biskupské náměstí č. 1. In: Historické sklo 2. Sborník pro dějiny skla. Čelákovice, 79-84.

Boháčová, I. - Frolik, J. - Petřićková, J. - Žegklitz, J. 1990: Příspěvek k poznání života a životního prostředí na Pražském hradě a Hradčanech Ein Beitrag zur Kenntniss des Lebens und der Umwelt auf der Prager Burg und in Hradčany. Archeologia Historica 15, 177-189.

Břečková, K. 2017: Středověké sklo z Opavy II. Nálezy skla z archeologických výzkumů na ulici Masařská 6, Pekařská - Kolářská a Mnišská - Mezi Trhy. Památky archeologické CVIII, 257-289.

Cílová, Z. - Kučerová, I. - Knižová, M. 2013: Hodnocení korozního poškození středověkých vitrají z území Čech - Evaluation of corrosion on Czech medieval window panes. In: Koroze a ochrana materiálů, vol. 57, no. 2, 41-49.

Cónová, I. - Gajdošová, I. - Lacková, D. 2006: Vitráže na Slovensku. 1. vyd. Bratislava.

Curková, M. - Černá, E. 2011: Sklo z počátku novověku z Ústí nad Labem - Předmostí, čp. 43. In: Historické sklo 4. Sborník pro dějiny skla. Čelákovice, 77-90.

Czihak, E. 1891: Schlesische Gläser. Breslau.

Černá, E. (ed.) 1994: Středověké sklo v zemích koruny české. Katalog výstavy. Most.

Černá, E. 2004: Svědectví archeologických nálezů okenních skel - Zeugnisse archäologischer Fensterglasfunde. In: Svorník 2/2004. Okna a dveře. Unicornis. Praha, 21-32.

Foltýn, D. a kol. 2005: Encyklopedie moravských a slezských klášterů. Praha: Libri

Galuška, L. - Macháček, J. - Pieta, K. - Sedlácková, H. 2012: The Glass of Great Moravia: Vessel and
Window Glass, and Small Objects. In: Journal of Glass Studies, vol. 54. The Corning Museum of Glass. Corning, 61-92.

Gyürky, K. H. 1986: Az Üveg. Katalógus. Monumenta Historica Budapestiensia. BTM. Budapest.

Himmelová, Z. 2000: Nálezy skla z Mikulčic (okr. Hodonín). In: Historické sklo 2. Sborník pro dějiny skla. Čelákovice, 85-100.

Karel, J. 2017: Kolekce fragmentů renesančního skla ze zámku Janovice u Rýmařova. In: Střední Morava: vlastivědná revue, Roč. 23, č. 44, 91-104.

Kaufmann, V. 2010: Archäologische Funde einer spätmittelalterlichen Glaserwerkstatt in Bad Windsheim. Handwerk, handel und geschichte.

Kiecoň, M. - Zezula, M. 2007: Opava. Drůbeží Trh. Číslo akce NPÚ Ostrava: 50/05. Zpráva o archeologickém výzkumu.

Kostillková, M. 1999: Okna Svatovítské katedrály. Pražský hrad.

Kouřil, P. - Prix, D. - Wihoda, M. 2000: Hrady českého Slezska. Brno - Opava.

Kozáková, R. - Frolik, J. 2011: Bohatý soubor skla v Chrudimi, Hradební ulici. In: Historické sklo 5. Sborník pro dějiny skla. Čelákovice, 75-90.

Lazar, I. - Willmott, H. 2006: The Glass from the Gnalić wreck.

Lněničková, J. 2004: Vývoj technik výroby okenního skla od středověku do 20. století. In: Svorník 2/2004. Okna a dveře. Unicornis. Praha, 13-20.

Losos, L. 2006: Vitráže. Praha.

Matějek, F. 1967: Opava před třicetiletou válkou (jako hospodářské středisko kraje). Časopis Slezského zemského muzea XVI, série B, 51-69.

Pankiewicz, A.-Siemianowska, S. - Sadowski, K. 2018: Jak interpretować 8-kilogramowy depozyt szkła z Ostrowa Tumskiego we Wrocławiu? In: Historické sklo 6. Sborník pro dějiny skla. Čelákovice, 21-49.

Podliska, J. 2003: Renesanční sklo z pražských archeologických výzkumů. In: Historické sklo 3. Sborník pro dějiny skla. Čelákovice, 21-34.

Sedlácková, H. 1997: Renesanční sklo a další archeologické nálezy z Nymburka. Libice nad Cidlinou.

Sedláckovaá, H. 2004a: Středověké sklo z Opavy - Mittelalterliches Glas aus Opava/Troppau. Památky archeologické XCV, 223-264. 
Sedlácková, H. 2004b: Archeologické nálezy skla z hradu Cvilín u Krnova, okr. Bruntál - Archäologische Glasfunde auf der Burg Cvilín (Schellenburg) bei Krnov (Jägerndorf), Bezirk Bruntál (Freudental). In: Vlastivědný věstník moravský LVI, 367-379.

Sedláčková, H. 2007: From the Gothic period to the Renaissance. Glass in Moravia 1450 - circa 1560. In: Studies in Post-Medieval Archaeology 2, 181-226.

Sedláčková, H. 2009: Soubor nálezů skla z archeologického výzkumu. In: Prix, D. a kol.: Kostel sv. Benedikta v Krnově-Kostelci. Ostrava, 172-178.

Sedlácková, H. 2010: Vypovídací hodnota archeologických nálezů skla na Moravě z období ca 1200-1550 (Teze) - Der Aussagswert archäologischer Glasfunde aus Mähren aus der Zeit um 1200-1550 (Thesen), Archeologia Historica 35, 359-366.

Sedláčková, H. 2011a: Středověké sklo na severní Moravě a přiléhající části Slezska. In: Majer, D. - Antonín, R.: Král, který létal. Moravsko-slezské pomezí v kontextu středoevropského prostoru doby Jana Lucemburského. Ostrava: Ostravské muzeum, 767-791.

Sedlácková, H. 2011b: Okenní a duté sklo z kostela sv. Martina. In: Kozák, P. - Prix, D. - Zezula, M. (eds.): Kostel sv. Martina v Bohušově. Bohušov, 285-306.

Sedláčková, H. 2012: Das Glas deutscher Provenienz in Mähren, Tschechische Republik. In: Glasproduktion. Archäologie und Geschichte. Beiträge zum 4. Internationalen Symposium zur Erforschung mittelalterlicher und frühneuzeitlicher Glashűtten Europa, 143-155.

Sedlácková, H. 2015: Sklo. In: Kolář, F. - Prix, D.- Zezula, M. eds.: Krnov. Historie - archeologie, Ostrava (NPÚ), 316-326.

Sedlácková, H. ed. 2019a: Glass in Brno and Moravia ca. 1200-1550. Assessment of finds. Vol. I.

Sedlácková, H. ed. 2019b: Glass in Brno and Moravia ca. 1200-1550. Catalogue of Glass. Vol. II.

Sedláčková, H. - Rohanová D. 2015: Středověké a renesanční sklo. In: Plaček, M. - Dejmal, M. a kol: Veselí nad Moravou Středověký hrad v říční nivě. Brno, 309-320.

Sedláčková, H. - Rohanová, D. et al. 2016: Renaissance and baroque glass from the Central Danube region. Brno.
Siemianowska, S. 2013: Średniowieczne i wczesnonowożytne szkła witrażowe odkryte na Ostrowie Tumskim we Wrocławiu w latach 1949-1961, 1963, część I, m-pis sprawozdania w Archiwum Ośrodka Badań nad Kulturą Późnego Antyku i Wczesnego Średniowiecza IAE PAN, Wrocław.

Šikulová, V. 1968: Pokračování záchranných akcí v areálu středověké Opavy. In: Přehled výzkumů 1967, 107-111.

Špaček, J. 2000: Nálezy středověkého skla ze Staré Boleslavi. In: Historické sklo 2. Sborník pro dějiny skla. Čelákovice, 101-107.

Šrámková, V. 2012: Současný stav poznání středověkého a raně novověkého sklářství na severní Moravě a přilehlých oblastech polského Slezska. Olomouc. Diplomová práce (Mgr.). Univerzita Palackého v Olomouci. Filozofická fakulta.

Štěpán, V. 1998: Sklářská hut’ v Mnichově u Vrbna pod Pradědem. Časopis slezského zemského muzea, série B, svazek XLVII, 23-43.

Štěpán, V. 2001: Sklárna v Bílé Vodě u Štítů. In: Severní Morava. Vlastivědný sborník, svazek 81, 3-14.

Štěpán, V. 2006: K historii sklářství na Jesenicku, Javornicku a Zlatohorsku. In: VI. Svatováclavské českopolsko-německé setkání. Jeseník, 44-61.

Štěpán, V. 2014: Dějiny dominikánského kláštera a kostela sv. Václava v Opavě.

Štěpán, V. - Štěrbová, J. 1999: Vývoj sklářského průmyslu na panství Branná. In: Severní Morava. Vlastivědný sborník, svazek 78, 17-30.

Štěpán, V. - Štěrbová, J. 2001: Sklářství na panství Velké Losiny. Časopis Slezského zemského muzea, série B, svazek L, 234-275.

Štěrbová, J. - Pavelčik, J. 1997: Macákové z Ottenburku (historie jednoho opavského domu ve světle archivních pramenů a archeologického výzkumu). In: Sborník prací Filozofické fakulty Ostravské univerzity. Historie (Acta Facultatis Philosophicae Universitatis Ostraviensis. Historica). Ostrava: Filozofická fakulta Ostravské univerzity v Ostravě, č. 5, 145-172.

Tomek, W. W. (ed.) 1882: Kosmův letopis český s pokračováním kanovníka Wyšehradského a mnicha Sázavského. Praha

Vad’urová, K. 2019: Středověké skleněné kroužky z Opavy. Časopis Slezského zemského muzea, série $\mathrm{B}$, svazek 68, 11-23. 
Vad’urová, K. 2021: Sklo z odpadních jímek na Drůbežím Trhu v Opavě a pozůstatky sklenářské dílny. Archaeologia historica 46/1, v tisku.

Verità, M. 2009: Venetian innovations in glassmaking and their influence on the European glass history. Online, cit. 20. 3. 2020: http://www.verre-histoire.org/colloques/innovations/pages/ p201_01_verita.html

Vondroušková, E. 2010: Okenní vitráže z Melic. Bakalářská diplomová práce. Masarykova Univerzita, Filozofická fakulta, Ústav archeologie a muzeologie. Brno.

Wedepohl, K. H. - Krueger, I. - Hartmann, G. 1995: Medieval led glass from northwestern Europe. In: Journal of Glass Studies 37, Corning - New York, 65-82.
Wedepohl, K. H. - Simon, K. 2010: The chemical composition of medieval wood ash glass from Central Europe. In: Geochemistry, Volume 70, Issue 1, 87-97.

Winter, Z. 1906: Dějiny řemesel a obchodu v Čechách. Praha.

Wyrobisz, A. 1968: Szkło w Polsce od XIV do XVII wieku. Wrocław.

Žegklitz, J. 2011: Výsledky archeologického výzkumu renesanční sklářské huti v Broumech. In: Historické sklo 5. Sborník pro dějiny skla. Čelákovice, $167-21$. 


\section{Insight to the windows of medieval and early post-medieval houses in Czech Silesia}

Although the closing of window openings with glass panes connected by lead frames is already documented in the late Roman period, in Central Europe the window glass spread much later. The findings of the oldest window glass in the Czech lands are associated with the sacral buildings on early medieval central settlements. In the High and Late Middle Ages, however, window glass spread to the urban environment and nobility residences.

In Silesia, glazed windows are documented as early as the $12^{\text {th }}$ century in Wrocław (Wyrobisz 1968, 108). A large set of stained glass was excavated on Ostrów Tumski (Siemianowska 2013; Pankiewicz - Siemianowska - Sadowski 2018, 49, ryc. 6-12). In Czech Silesia and northern Moravia, glazed windows featured since the 13 th century. In this period, window glass is represented mainly by fragments of corroded window panes and stained glass.

The existence of stained glass windows in Czech Silesia is evidenced by finds from the 13th century from the church of St. Benedict in Krnov-Kostelec and the church of St. Martin in Bohušov. In the church of St. Benedict, only one fragment of a corroded window pane was found (Sedlácková 2009, 172-173). Large series of window glass containing more than 100 fragments of colorless, light green, violet, and amber-yellow glass were found in the church of St. Martin (fig. 6: 14-15; Sedlácková 2011b, 292-294). Analyzed samples revealed that stained glass was made from wood-ash glass of archaic composition and lead glass (Sedlácková 2011b, 294, 303). Colored and colorless window panes from Opava-Lower square and Poultry Market (Sedlácková 2011a, 769, 775; 2011b, 299) evidenced that even wealthy burghers could afford glazed windows in their households since the second half of the 13th century.

A large series of stained glass were found during the excavation of the Dominican monastery in st. Wenceslas church (fig. 5; fig. 6:1-12). The set contained over 400 fragments of colored stained glass, on several dozens of which original contour painting was still visible despite the corrosion. These stained glasses are probably remains of the oldest windows of this church dated to the first half of the 14th century. Analyses of five samples (tab. 1) revealed that these glasses were made of potassium-calcium glass with low $\mathrm{SiO}_{2}$ content, while the content of the alkaline components $\mathrm{K}_{2} \mathrm{O}$ and $\mathrm{CaO}$ was relatively high. These glasses are results of the same production technology and, according to K. H. Wedepohl, belong to the wood-ash glass, which was produced in Germany between 1000-1400 (Wedepohl - Simon 2010).

Another large series of window glass comes from refuse pit no. 505 on Poultry Market in Opava, filled at the end of the $14^{\text {th }}$ century and during the $15^{\text {th }}$ century. This refuse pit contained at least 300 fragments of window panes made from greenish wood-ash glass of similar composition to regional products of the High Middle Ages (fig. 10; tab. 2: A6). Nine fragments of window discs, stained glass decorated with Schwarzlot (fig. 7) and lead straps, which were used to connect panes or discs, were found in the same pit. Engraved lines were drawn on parts of the panes to prevent the breaking of a larger piece of glass when retouching edges of the window panes. The shape of these fragments corresponds to the window glass production waste excavated in Bad Windsheim (Kaufmann 2010, 43). Window glass from the Poultry Market thus proves the existence of glazier's workshop that operated on the site in the first half of the $15^{\text {th }}$ century. The glazier was probably supplied with sheet glass from regional glasshouses. However, interpretation of these findings raises more questions. How long had the glazier been operating here? Did he produced also stained glass, and if so, who ordered such a luxury and expensive product?

Except for window panes, discs with sealed or folded rims have been used for glazing since the $14^{\text {th }}$ century as evidenced by archeological findings from several sites in Opava and Ostrava. The diameters of medieval and early post-medieval window disc with folded rims oscillate between $80-100 \mathrm{~mm}$, larger discs with diameter 130-140 mm are less common. In the case of discs with sealed rims, we observe greater variability in dimensions, which ranges from 100 to $160 \mathrm{~mm}$ (graf 1). Fragments of window panes were 
also excavated at castles Fürstenwalde (Kouřil - Prix - Wihoda 2000, 154), Vikštejn, and near the walls of the Silesian-Ostrava castle. Further finds of window glass come from Cvilín castle (Sedláčová 2004b, 374). In the $15^{\text {th }}$ century, the number of window discs increased significantly, at the expense of window panes and stained glass.

Findings from the courtyard between Horní náměstí-Pekařská-Kolářská street illuminate what medieval windows of bourgeois houses looked like (fig. 8). In the refuse pit no. 508 filled in the late $14^{\text {th }}$ and $15^{\text {th }}$ century, there were excavated emerald-green stained glass, at least 30 simple window discs simple and discs with optic-blown decoration of ribs and 55 triangular fillings. Similar disc with optic-blown ribs comes from Mnišská-Mezi Trhy (Břečková 2017, 270-271) and Cvilín castle (Sedláčová 2004b, 374). Window glass with optic-blown decoration sporadically featured in the layers from the second half of the $15^{\text {th }}$ century. Several fragments were found in Brno and Chrudim. Due to the absence of analogical finds from other sites and wood-ash glass composition of a disc from Opava (tab. 2: A17), we can assume they have been manufactured in Moravian or Silesian glasshouses.

In the early post-medieval period, window glass still belonged to the basic repertoire of Silesian and Moravian glassworks. Direct evidence was found in glasshouse Sklená near Pusté Žibřidovice and Nová Seninka (Sedlácková - Rohanová et al. 2016, tab. 32: 506-508). In the Renaissance period, window glass was represented mostly by undecorated window panes (rectangular, rhombic, or hexagonal) and discs manufactured by the „crown“ technique.

We can get an idea of the various compositions of the windows not only based on archaeological material but also from numerous paintings depicting the interiors of Renaissance houses and palaces. The huge consumption of window discs in the $16^{\text {th }}$ and $17^{\text {th }}$ centuries is illustrated by historical written sources concerning the import of glass. Fifteen whole discs and 587 fragments were excavated at Horní náměstí, on the site, where the house of Macák from
Ottenburk was built in Renaissance. These discs diameter vary from 80 to $94 \mathrm{~mm}$, larger discs are exceptional (Štěrbová - Pavelčı́k 1997, 159).

In addition to potassium-calcium glass window discs, imported sodium-potassium-calcium glass window glass was found in Opava-Dolní náměstí 18 and Pekařská-Kolářská street. In refuse pit no. 512 on Pekařská-Kolářská dated to the end of $15^{\text {th }}$ to the $16^{\text {th }}$ century at least 11 window discs with folded rims, 2 discs with sealed rims and one disc with cut rims were found (fig. 11: 2-4). One of the discs was made from a glass of similar composition to Venetian Common glass (tab. 2: A8). Vitrum blanchum, another type of Venetian glass, was identified in case of the disc from greyish glass found at Dolní náměstí 18 (tab. 2: A9). This disc was found in a refuse pit filled in the turn of the $16^{\text {th }}$ and $17^{\text {th }}$ century together with seven other discs (fig. 11:5-7).

Based on the finds of window glass, it is probable that in the $16^{\text {th }}$ and early $17^{\text {th }}$ centuries almost all houses in the Opava city center and several houses in Ostrava already had glazed windows. Hexagonal window panes and glass waste from their manufacture were found in Krnov, in the layer from the $16^{\text {th }}$ and first half of the $17^{\text {th }}$ century (Sedlácková 2015, 320-321). Besides the above-mentioned sites, Renaissance window glass comes from Sovinec castle (fig. 11:1), Starý Jičín and Janovice castle (Karel 2017, 95).

It is not possible to determine exactly what was the proportion of window glass of regional and foreign production or what part of the total volume of glass production was the window glass. However, it is generally accepted that the growing demand for window glass in the $13^{\text {th }}$ and $14^{\text {th }}$ centuries was a significant impetus for the establishment of first glassworks. At first, it was mainly the supply of glass for church buildings and nobility residences, later more and more often for burgher houses. Demand continued to grow during the late Middle Ages, along with increasing housing demands. In the early post-medieval archaeological material, window glass is already a common part of almost all series. 


\section{Mgr. Kateřina Vad'urová}

- Ústav archeologie a muzeologie,

Filozofická fakulta, Masarykova univerzita,

A. Nováka 1, 60200 Brno, Česká republika

katkabreckova@mail.muni.cz 
